\title{
Características morfológicas da planície de inundação do rio Atibaia, entre Campinas e Jaguariúna, SP, Brasil
}

\author{
Luís Eduardo de Oliveira Muraro ${ }^{1}$; Suel Yoshinaga Pereira ${ }^{1}$, Paulo Ricardo Brum Pereira² \\ 1. Instituto de Geociencias, Unicamp, Rua carlos gomes 250, 13083-855, Campinas, SP. \\ 2. Instituto Florestal, Secretaria da Infraestrutura e Meio Ambiente, São Paulo, SP. \\ E-MAIL: LUIS.MURARO@YAHOO.COM.BR; SUELIYOS@UNICAMP.BR, PAULOBRUMPEREIRA@gMALl.COM.
}

Morphological characteristics of the Atibaia river floodplain, Campinas and Jaguariuna muncipalities, SP, Brazil

Abstract: Alluvial plain is a complex and dynamic system situated near the base level of watercourses and is the result of sedimentation and erosion processes. It is an area of hydrological risk for urban and peri-urban occupation, due to seasonal floods. The Atibaia river plain is an extensive border area (approximately $34 \mathrm{~km}^{2}$ ) within the municipalities of Campinas, Jaguariúna and Paulínia. It is located in the transition between the Peripheral Depression and the Atlantic Plateau. The plain forms a small sedimentary basin, formed above the sedimentary rocks of Itarare Subgroup, due the tapering of the river channel by diabase rocks downstream, and gneiss rocks upstream. It exhibits two terraces with paleomeanders and paleo-channels, old point bars and levees. Small elevations are present, and recent NW and SE migrations of meanders were recorded. Wetlands and swamps are areas where the groundwater reaches the surface, accumulates and flows slowly to the river.

\author{
Manuscrito: \\ Recebido:27/03/2019 \\ Corrigido: 17/mai/2019 \\ Aceito: $21 / 08 / 2019$ \\ Citação: Muraro, L. E. 0.; Pereira, S. Y.; Pereira, \\ P. R. B. (2019). Características morfológicas \\ da planície de inundação do rio Atibaia, entre \\ Campinas e Jaguariúna, SP, Brasil. Terræ \\ Didatica, 15, 1-18, e19029. doi: 10.20396/ \\ td.v15i0.8655083
}

Palavras-chave: Rio Atibaia, Feições geomorfológicas, Planície aluvionar.

\section{Introdução}

Planícies aluvionares são consideradas zonas de recarga ou descarga de sistemas hidrogeológicos locais a regionais e estudos recentes têm demonstrado a complexidade e importância destes aquíferos (Brunke \& Gonser, 1997; Rohde, Ray \& Howard, 2017).

Elas fazem parte dos "Ecossistemas dependentes de Águas Subterrâneas" (EDAS, equivalente de Groundwater dependent Ecosystem - GDE, The World Bank 2006). EDAS compreendem um complexo e diverso (e biodiverso) setor de ecossistemas mundiais que se caracterizam pelo grau de dependência da água subterrânea para manter sua composição e função ambiental (Hatton \& Evans, 1998; Murray, Zeppel, Grant \& Eamus, 2003). As águas subterrâneas desempenham um papel particularmente relevante para a sustentabilidade de certos tipos de ecossistemas aquáticos, terrestres e costeiros, vitais para a manutenção da integridade ecológica, seja em regiões de climas úmidos ou secos. O fluxo de base do curso de água é proveniente da descarga da água subterrânea e resulta da permeabilidade do aquífero, geologia local e regional, armazenamento na margem e na planície de inundação e da topografia do nível de água (potenciometria do aquífero). Estudos internacionais sobre EDAs, indicam sua importância e a necessidade da manutenção destes ecossistemas em função do impacto de mudanças climáticas, atividades agrícolas (irrigação por águas de reuso) e urbanização (efluentes domésticos).

A análise da planície envolve toda a área de drenagem, pois situa-se no nível de base do rio e, portanto, todas as águas de escoamento superficial e subsuperficial se direcionam a ela.

Geomorfologicamente, a planície aluvionar (ou de inundação) pode ser definida como uma macroforma que é caracterizada por uma típica assembleia de mesoformas (barras de pontal, diques marginais, lagoas, pântanos, etc.) e até microformas (marcas de onda, dunas) (Alexander \& Marriot, 1999; Marriot, 2004). 
De acordo com Stanford \& Ward (1993), a planície aluvionar está saturada pelas águas do rio e pela influência lateral das águas subterrâneas; a água e materiais são transportados mais rapidamente por meio dos aquíferos aluvionares, dentro de uma rede ou camadas de paleocanais de elevada porosidade.

As aluviões são um importante testemunho da formação e das dinâmicas dos canais fluviais, da zona ripária, das vertentes, do paleoclima, da vegetação e da própria bacia hidrográfica.

É sabido que as enchentes e inundações estão se tornando cada vez mais frequentes e mais violentas devido as mudanças climáticas e a acelerada ocupação e impermeabilização do solo. Mesmo longe dos centros urbanos o volume de escoamento superficial fica comprometido devido aos picos de vazões das cheias (Vendrame \& Lopes, 2015). Segundo Benson \& Clay (2003) o perigo de inundação é "um evento hidrológico que tem potencial de causar prejuizo e danos".

As planícies aluvionares sofrem também transformações antrópicas (como aterros e escavações), que modifica o modelado natural, considerado por Pellogia (2005), como registro sedimentar holocênico (e pleistocênico). As transformações antrópicas são decorrentes de processos tectogênicos nas planícies urbanas ou periurbanas (Pellogia 2005).

Desta forma o objetivo do presente artigo visa caracterizar as planícies do rio Atibaia e identificar os componentes das planícies que indicam os processos de assoreamento e sedimentação destes ambientes. As frequentes inundações e alagamentos e a expansão da ocupação humana na planície a transformaram em área de risco hidrológico (CPRM, 2013). O entendimento da planície é essencial para entender a dinâmica e ambiente de vital importância para a manutenção da saúde dos rios.

\section{Fundamentação teórica}

As planícies aluvionares podem ser consideradas como sistemas rio-planícies e apresenta diversos ecossistemas como o rio, várzeas ou brejos, ilhas ou zonas de transição (Rocha, 2011), possuindo diferentes formas e espessuras. São notadamente baixios próximos ou muito próximos do canal. Elas servem como agentes reguladores da bacia, sendo responsáveis pela reservação livre das águas excedentes das cheias e inundações (Perez, Donzelli \& Lepsch, 1980). São o tipo mais comum de sedimentação fluvial que existe.
Esta contém estruturas geomorfológicas muito complexas, além de possuírem várias feições e formas, como morros, bacias de decantação, apresentam uma série de dinâmicas que podem influenciar ou não diretamente no comportamento do rio em seu leito menor.

A deposição do material está ligada diretamente com as cheias do leito, bem como o assoreamento marginal que é resultado tanto pela ação antrópica como dos próprios movimentos laterais (Zancopé \& Perez, 2006). Ao ocorrer o transbordo do canal os materiais que são transportados, que vão desde detritos em formas de grãos e partículas, passando por matérias orgânicas, lixo, produtos oriundos da antropormifização, até matacões. Outros sedimentos de origem clástica como areias, cascalho e até mesmo lama são constantemente depositados no fundo do leito e margens dos rio e dos córregos da planície. Estes sedimentos, denominados de aluvião (CPRM, 1974), muitas vezes, com o extravasamento do canal pelas águas do rio, passam a ser depositados também em terras inundáveis e alagadiços. Os depósitos nestas áreas fazem com que sejam classificadas como planícies aluvionares (Christofoletti, 1980).

A aluvião pode variar de alguns centímetros até metros de espessuras. Um fator importante e que deve ser considerado na sua formação é que primeiramente aparecem nos baixios laterais que se encontram imediatamente após os diques marginais ao leito principal (Perez et al., 1980). Os diques são estruturas mais altas que encontram-se entre o canal principal do rio e a planície de inundação (Perez et al., 1980). Geralmente de material mais resistente, sua composição na região da planície é de origem diabásica ou basáltica. Os diques geralmente encontram-se a poucos centímetros ou metros de terrenos aplainados denominados de pediplanares (Perez et al., 1980). Estas feições contribuem para a formação de micro-bacias de decantação onde ocorrem grande deposição aluvionar (Perez et al., 1980). Outra dinâmica do rio muito comum na área de estudo é o da "migração dos meandros" (Leinz \& Amaral, 1995). Existe portanto três processos que alteram e agem fortemente sobre a configuração da planície. O primeiro deles é o erosivo onde as margens são moldadas ora de forma constante, ora de forma abrupta pelas curvas do rio. O segundo denominado de deposicional (Popp, 1998) é quando o material deposita-se de forma irregular criando as chamadas planícies de deposição. E finalmente o terceiro quando ocorre a esculturação do terreno 
pela força da inundação originando, montes, morrotes e bancos sedimentares. Devido a movimentação do material pela águas das cheias, há uma grande facilidade de esculturação da topografia local no caso pelo Rio Atibaia.

As aluviões são um importante testemunho, uma vez que, as análises de campo permitem obter dados históricos das dinâmicas dos canais fluviais, da zona ripária, das vertentes, do paleoclima, da vegetação e da própria bacia hidrográfica. Podem ser extraídos dados variados, como por exemplo: geomorfológicos, geológicos, hidrológicos, hidrogeológicos, paleobotânicos, paleoclimáticos, pedológicos, antropomórficos, entre outros, a fim de compreender sua dinâmica e formação. A maioria do material provém das escavações realizadas pelo rio em seu leito e de águas pluviais. No solo ou na rocha sã, as águas ocasionam o aprofundamento da calha e fornecem grande parte do material que ao ser transportado pelas cheias são depositados nos sítios aluviais (Christofoletti, 1980). Este processo realizado de forma constante cria algumas feições típicas das planícies, como os terraços fluviais (Christofoletti, 1980). Os terraços fluviais são constituídos, geralmente, por material aluvionar. Estão dispostos em diferentes níveis, indo dos mais afastados, mais altos e mais antigos e a medida que se aproximam do nível do rio tornam-se mais jovens e mais baixos. A origem dos terraços aluvionares está ligada a algumas causas como, por exemplo: mudanças climáticas, regime hidrológico, processos tectônicos, vulcanismo, alterações geomorfológicas diversas, etc. O principal causador desta mudança é o chamado nível de base (CPRM, 1974). Nível de base, é uma linha imaginária altimétrica onde o rio não consegue mais erodir. Neste local predomina o acúmulo e deposição de material carreado e transportado (CPRM, 1974). As altitudes e as áreas diferenciadas são evidências do comportamento do curso d'água. Outra feição muito comum encontrada são os diques marginais (Christofoletti, 1980). Verdadeiras barreiras naturais de tamanhos do mais variados separam o rio da Planície. A dinâmica do curso faz com que o rio abandone algumas áreas antes ocupadas pelo seu leito, criando-se assim os denominados meandros (Christofoletti, 1980) (Figura 1).
Ao migrar e abandonar seu leito inicial, o rio dá origem a lagos e lagoas. Toda esta estrutura começa com os depósitos residuais de materiais clásticos, como por exemplo a areia e a argila. Estes materiais passam a ter um papel fundamental na formação de pequenos morros e outras feições.

As feições podem ser classificadas como Feições de acumulação e dissecação, definidas a seguir.

- Feições Geomorfológicas Fluviais de Acumulação: as feições de Acumulação (Verstappen, 1983) referem-se ao material depositado que foi anteriormente removido e transportado pelos agentes de erosão. Estes agentes no caso da planície são as águas fluviais, principalmente as das cheias e enchentes.

- Barras de Pontal: desenvolvem-se nas margens convexas dos rios meandricos. $\mathrm{Na}$ sua evolução agem diretamente na acreção lateral. Este processo culmina com a acumulação de sedimentos verticais laterais. Nas partes onde o rio é retilíneo as barras de pontal são chamadas de barras laterais (Charlton, 2008).

- Diques Marginais: os diques marginais (Zancopé, 2008) ou Natural Levee (Charlton, 2008), fazem parte dos modelados da planície, são elevações que se estendem paralelamente ao longo do canal do rio. São de baixa altitude e sua formação está ligada diretamente a deposição fluvial. São geralmente compostos por deposição arenosa e sua acumulação se deve às cheias do rio e o consequente transbordo do canal principal. Os diques marginais

\begin{tabular}{c|c|c|c|c|c}
\hline (C) Terrae Didat. & Campinas, SP & v.15 & $1-18$ & e019029 & 2019 \\
\hline
\end{tabular}


agem como agentes retentores das águas fluviais e pluviais impedindo um escoamento rápido.

- Paleodrenagens: são depósitos lineares fluviais e correspondem a uma drenagem pretérita. As paleodrenagens podem ser de dois tipos. O primeiro tipo é quando são classificadas como uma drenagem pré-existente (Tucci, 2012), ou seja, um paleocanal (Christofoletti, 1980; Charlton 2008) e o segundo como sendo um meandro abandonado (Zancopé, 2008) onde ocorre sua "colmatação", ou seja, ocorre seu preenchimento sedimentar (Suguio, 2003).

- Feições Geomorfológicas Fluviais de Dissecação

- Terraços: os terraços aluviais (Zancopé e Perez, 2006) possuem formação plana e levemente inclinados. Apresentam uma quebra de linha em relação ao perfil do rio. São registros históricos de deposições do canal do rio e das planícies anteriores. Estas últimas, estão situadas em nível imediatamente inferior ao terraço. Os terraços são compostos por material aluvionar (Perez Filho et al., 1980). São exemplos desta evolução: geomorfologia, processos tectônicos e mudanças climáticas. Estes fatores atuam diretamente ou indiretamente na sua forma do relevo devido ao soerguimento epirogenético, ao falhamento ou a captura do rio por processos erosivos. Ocorre neste caso a mudança do Nível de Base.

- Pequenas Planícies e Pequenos Terraços: um misto de pequenas planícies e terraços. São áreas planas onde são encontrados meandros abandonados que possuem cordões deposicionais de sedimentos (IBGE, 2009). Na planície as bordas de terraço fazem a divisa entre as aluviões mais antigas e a atual área inundável. Sua formação está ligada diretamente à variação do nível de base (Christofoletti, 1980). Conhecidas também como Feições de Dissecação (Verstappen, 1983) possuem agentes que ocasionam desgaste e erosão nos materiais. São agentes importantes na função de dissecação, as águas pluviais e a ação eólica.

- Meandros Abandonados: o meandro abandonado ou Oxbow Lake (Charlton, 2008) é uma avulsão, ou seja, um seccionamento do canal principal. São encontrados em planícies de inundação geralmente largas, onde a declividade é relativamente baixa.

- Anomalias de Drenagem: são feições do canal de drenagem onde ocorrem bruscas mudanças no curso do rio (Almeida, 1964). Essa anomalia é facilmente perceptível pois o padrão se altera de forma bem acentuada.

Os diferentes tipos de ambientes encontrados em planícies apresentam-se como subambientes (Bayer, 2014), associados as diferentes zonas de sedimentação, que vão desde a planície inundada até os baixios sazonais e se fará em ambientes e subambientes da seguinte forma:

- Ambientes Sedimentares Associados à Planície Aluvial: ligados diretamente as características do ciclo hidrológico. Este subambiente está dividido em dois subambientes aluvionais:

- Subambiente de Planície Raramente Inundável: com baixa acreção vertical (Bayer, 2014), possui altitudes mais elevadas e ocasionalmente sofrem com a cheias.

- Subambiente de Pântano: localiza-se geralmente na parte mais distante da planície aluvional. No geral é descontínuo, possuindo características muito peculiares de um para outro. Devido a sua distância sofre pouca influência das cheias do rio. Neste subambiente são encontradas geralmente nascentes ou logo abaixo dos mesmos, lentes de argila.

- Campos Úmidos são formações raras e particulares (Tannus \& Assis, 2003) 2004). São assim chamados por serem compostos por várias nascentes. Seu substrato de vegetal é composto principalmente de plantas herbáceas e subarbustivas. Em alguns casos são encontrados uns poucos espécimes de pequeno e médio porte. Compõem naturalmente mosaicos de terrenos úmidos e alagadiços de savanas (cerrado), matas ciliares e planícies de 
inundação. Sua flora pode ser rica em quantidade de indivíduos, mas é relativamente pobre em espécies. Estas formações são apresentadas por suas características morfológicas peculiares de alagadiços.

- Ambientes Sedimentares Associados ao Canal Principal: Devido a sua proximidade com o canal, sofrem influência direta e constante em épocas de cheias. Dividem-se em:

- Subambiente do canal principal: Mesmo dentro do leito menor do rio encontramos partes integrantes da aluvião. Contendo um talvegue bem definido, somente em casos extremos este subambiente não sofre ação direta das águas do canal principal.

- Subambiente de canais secundários: Dos trechos a serem estudados a foz dos rios secundários são um dos ambientes mais dinâmicos encontrados na planície.

- Subambiente de Barras Laterais: Devido à senilidade do rio, o talvegue sinuoso fornece material para forte deposição lateral. Criam-se assim bancos de areia com topografia suave e levemente inclinados.

- Subambiente de Bancos Centrais e Ilhas

- Subambiente de Diques Marginais Também conhecidos como leeves (Bayer, 2014) são formas alongadas e espalham-se ao longo do canal principal e dentro da própria planície aluvial.

Os estudos sobre a classificação morfológica e hidrológica dos rios fornecem bases para a gestão e proteção destes corpos de água. Rosgens (1994) apresenta um classificação de rios naturais em função principalmente da declividade do rio (sentido longitudinal), seção do canal e forma do rio. Em função da classe do rio, há o aparecimento das planícies e de sua tipologia. Rinaldi, Gurnell, González del Tánago, Bussettini \& Hendriks (2016) apresentam uma classificação de rios baseada em hierarquia, análises multi-escala e hidromorfologia, onde as formas do curso do rio (canais retilíneos a anastomosados) e a tipologia da planície de inundação (alta energia e planícies não coesivas a baixa energia e planícies coesivas), dentre outros parâmetros. Strick, Ashworth, Awcock \& Lewin
(2018) analisaram as feições de barras de pontal em diversos locais do rio Mississipi e as categorizou em três unidades geomorfológicas distintas; o estudo do rio meandrante baseado na morfologia das barras de pontal e de sua geometria pode contribuir ao entendimento da heterogeneidade dos depósitos de subsuperficie do meandro

\section{Área de estudo}

A área de estudo abrange a planície do rio Atibaia e suas vertentes e encontra-se distante à 34 $\mathrm{km}$ do centro da cidade de Campinas; faz o limite entre os municípios de Campinas, Jaguariúna (N) e Paulínia (NO), estando localizada entre as seguintes coordenadas $22^{\circ} 44^{\prime} 33^{\prime \prime} \mathrm{S}, 4^{\circ} 07^{\prime} 28^{\prime \prime} \mathrm{W}$; $22^{\circ} 45^{\prime} 30^{\prime \prime} \mathrm{S}, 47^{\circ} 07^{\prime} 19^{\prime \prime} \mathrm{W} ; 2^{\circ} 44^{\prime} 07^{\prime \prime} \mathrm{S}, 47^{\circ} 00^{\prime} 49^{\prime \prime} \mathrm{W}$ e $22^{\circ} 44^{\prime} 46^{\prime \prime} \mathrm{S}, 4^{\circ} 00^{\prime} 58^{\prime \prime} \mathrm{W}$, ou coordenadas UTM $\mathrm{E}=284000$ a $294000 \mathrm{~m}$ e $\mathrm{N}=7481000$ a $7486000 \mathrm{~m}$ (datum Córrego Alegre).

Do centro do Distrito de Barão Geraldo, até a área de estudo são percorridos $17 \mathrm{~km}$. Seus acessos principais são pela Rodovia Campinas-Paulínia (SP-332), Rodovia Campinas-Mogi Mirim (SP340), pela estrada municipal da Rhodia (CAM212), além de estradas vicinais. A planície apresenta uma área de cerca de $34 \mathrm{~km}^{2}$ (Fig. 2).

A área de estudo situa-se na Feição Climática I e Célula Climática Ib (Pereira 1997), com precipitação média anual variando entre 1374 e 1546 $\mathrm{mm}$, temperatura média anual entre 29 e $21^{\circ} \mathrm{C}$, evapotranspiração potencial média anual entre 97 e $1044 \mathrm{~mm}$, excedente hídrico variando de 380 a $564 \mathrm{~mm}$ ao ano e déficit hídrico anual baixo, entre 2 e $5 \mathrm{~mm}$. O trimestre menos chuvoso compreende junho, julho e agosto, e o mais chuvoso, janeiro, fevereiro e março (Pereira, 1997).

A hidrografia da área de estudo consiste no rio Atibaia que corta a planície de leste para oeste e de seus afluentes, o córrego São Francisco na margem direita do rio e a oeste da área, e outro córrego, sem nome, que dasagua no rio Atibaia na margem esquerda na porção oeste da área. A vazão média natural do rio Atibaia, na região da área de estudo é de 36,5 m3/s (Posto Rio Acima, série histórica 1930-1973, http:// arquivos.ambiente.sp.gov.br/ portalnovomedia/2012/01/modulo_aguas.pdf)

A planície aluvial da área de estudo encontra-se sobreposta as rochas sedimentares, corpos de diabásio e rochas cristalinas da região norte/noroeste do município de Campinas.

As rochas do Complexo Itapira são as mais anti- 


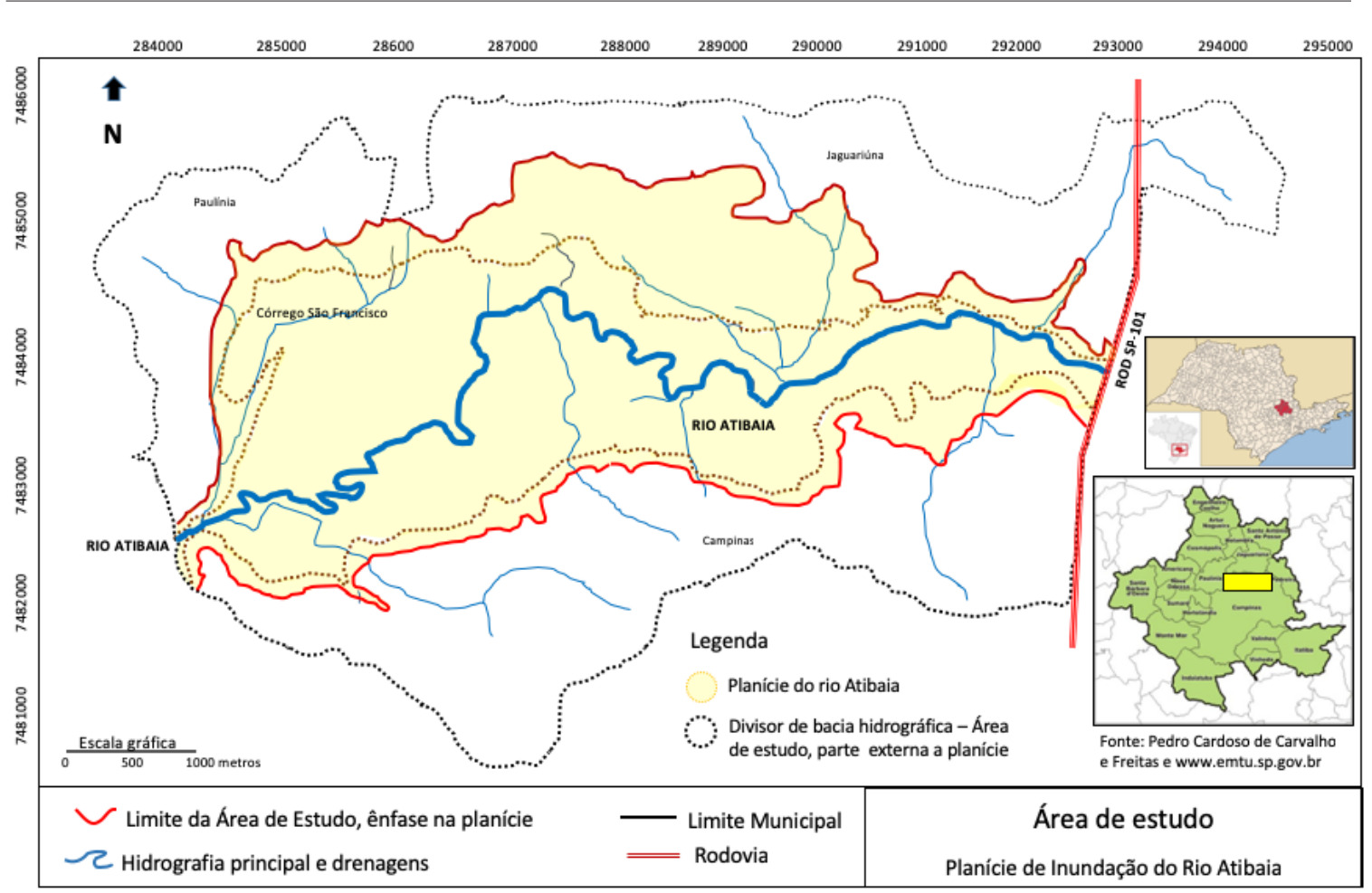

Figura 2. Área de estudo: a planície do rio Atibaia (em amarelo e contornada em vermelho) e o divisor hidrográfico (com contorno pontilhado preto). (Base Cartográfica: IBGE 1978, escala 1:10.000)

gas de idade do Proterozóico Médio, e apresentam-se como gnaisses indiferenciados e estão situadas na porção leste. As rochas do Proterozóico Superior correspondem a Suíte Granítica Jaguariúna caracterizadas como hornblenda-biotita granitos pofiríticos ou facoidais, cinza róseos e biotita granitos foliados, rosa acinzentados a rosa rosados (IG, 2009).

As rochas da Bacia Sedimentar do Paraná correspondem ao Subgrupo Itararé, de idade Carbonífero-Permiano e são caracterizadas como arenitos feldspáticos com estratificação cruzada associados a conglomerados, ritnitos turbidíticos, associação faciológica de diamictitos maciços, e arenitos, que apresentam 3 fácies: 1 - arenitos médios a grossos arcosianos e conglomerados, 2 - arenitos com estratificação cruzada e arenitos médio ou finos e 3 - arenitos finos a médios com estratificação acanalada. Ocorrem na área as intrusões como diques e sills de Diabásio, de idade Jurássico-Cretáceo, cinzas escuros e pretos.

Há uma cobertura cenozóica na margem direita do rio Atibaia, constituídas por argilitos, siltitos e arenitos. A aluvião consiste de sedimentos inconsolidados, constituídos por areia, silte, argila e cascalho e se desenvolve ao longo do Rio Atibaia, que são de idade Quaternária.

Uma síntese do mapa geológico da região de estudo é apresentada na Figura 3.
Em relação às águas subterrâneas, a planície caracteriza-se como aquifero freático, com nível de água raso e ótima capacidade de reservação (Muraro, Pereira \& Pereira, 2016). Os cambissolos aparecem ao norte e a nordeste da planície. São solos pouco desenvolvidos e como estão aliados às altas declividades, são muito suscetíveis à erosão (IBGE, 2009). Os latossolos vermelhos ocorrem sobre os diabásios e ocorrem em grande área nas margens direita e esquerda da área de estudo, nas vertentes a oeste, encontram-se latossolos vermelhos-amarelos. Os gleissolos são solos hidromórficos, muito encharcados e no geral encontram-se em contato direto com o aquifero freático.

De acordo com Embrapa Solos (2018), ocorrem geralmente nas partes mais próximas a calha do rio, várzeas e em alguns baixios como meandros migrados e no fundo das bacias de decantação. Existem dois tipos: distróficos (ácidos) e eutróficos (básicos). Pouco desenvolvido apresentam no horizonte A uma alta quantidade de carbono em relação aos outros horizontes. Isto se deve ao acúmulo de matéria orgânica proveniente da decomposição de vegetais e animais.

Os Argissolos Vermelho-Amarelo são solos minerais com horizonte $B$ textural, não hidromórficos, com seqüência de horizontes bem definida do tipo A, B, C e R. Situados em áreas onde o relevo 


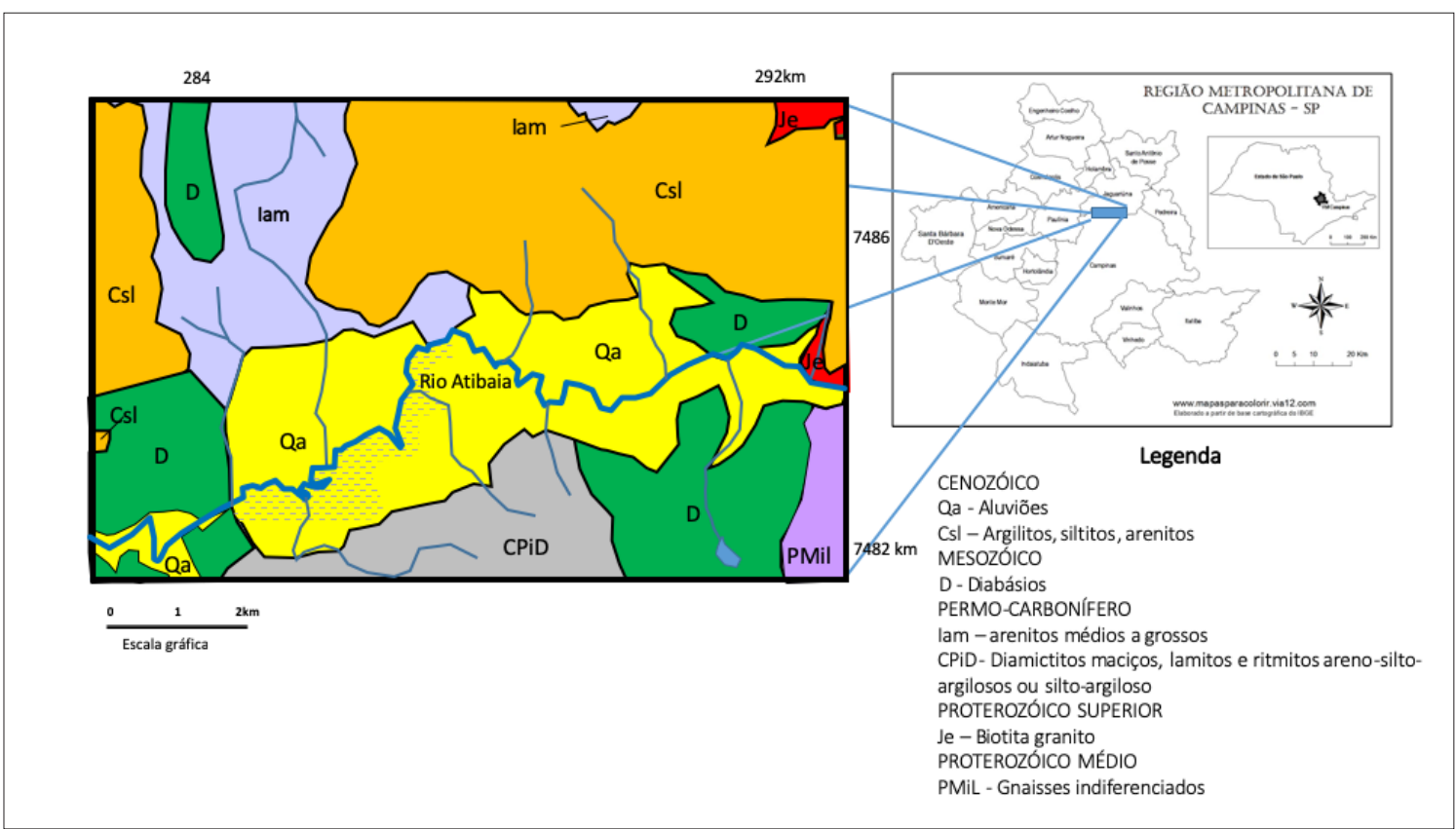

Figura 3. Mapa geológico simplificado da região da planície do rio Atibaia. Os depósitos quaternários da Planície estão representados pela cor amarela (Qa) (Modificado de IG, 2009)

é ondulado e fortemente ondulado. Nas vertentes da porção leste onde ocorrem rochas gnáissicas e granitóides.

Os remanescentes de vegetação de terra firme são em sua maioria compostos por espécies da Floresta Estacional Semidecidual. São ainda encontrados raríssimos fragmentos de Savana (Cerrado).

\section{Materiais e métodos}

(a) Pesquisa bibliográfica: a busca por fundamentação teórica, referenciadas relativas, a por exemplo, caracterização morfológica da planície, dinâmica do rio Atibaia, uso e ocupação das terras e os conflitos com a questão das inundações periódicas foi realizada no sentido de embasar e elaborar os procedimentos metodológicos. Os materiais bibliográficos contribuíram com noções, que foram usadas posteriormente, no estudo da área da planície. Este entendimento trouxe uma melhor percepção de suas dinâmicas e morfologia. Relatos dos moradores, também auxiliaram para melhor entender todas as práxis nela contida.

(b) Bases cartográficas: as cartas topográficas são da Secretaria de Economia e Planejamento do Governo do Estado de São Paulo, Subdivisão de Coordenadoria de Ação Regional, Divisão de Geografia e obedecem, o chamado Plano Cartográfico do Estado de São Paulo, de 1978. As cartas mais antigas apresentaram uma topografia mais original para a identificação das feições, sem muita interferência antrópica. A análise por fotointerpretação junto com as cartas topográficas de 1:10.000 permitiu identificar os limites externos da Planície, bem como as suas respectivas feições internas.

As seguintes cartas topográficas foram utilizadas como base para os estudos, com os respectivos códigos:

B. Bananal - SF.23-YA-V-4-NE-B,

B. Tanquinho Velho - SF.23-Y-A-V-2-SE-F,

Barranco Alto - SF.23-Y-A-V-2-SE-E e

Vila Lutécia - SF.23-Y-A-V-4-NE-A.

Os mapas estão em escala 1:10.000 com linhas de cota de $5 \mathrm{~m}$.

As imagens atualizadas do Google Earth Pro (Imagens da Digital Globe) da planície foram utilizadas para delimitação das feições geomórficas e uso e ocupação da terra.

(c) Atividades de campo: foram realizadas para a delimitação das feições observadas em cartas topográficas e imagens de satélites. A princípio, dois pré-trabalhos de campo foram realizados. Estas visitas permitiram traçar estratégias, adotando assim os melhores procedimentos e métodos investigativos. Com as visitas, foram observadas diferentes formas de relevo existentes na planície. As observações foram realizadas primeiramente com a identificação local das feições morfológicas. Em um segundo momento, realizaram-se visitas aos divisores, os 
quais, permitiam uma melhor visualização geral da planície. A partir destas visitas pode-se ter uma noção geral do mosaico morfológico que compõe a planície. As visitas terminaram em pontos de alta cota, permitindo ter uma visão geral da Planície. Nestes trabalhos de campo foram observados e detalhados vários componentes da planície.

(d) Tratamento e interpretação de dados: os seguintes mapas de trabalho foram elaborados para o estudo:

- Mapas hipsométrico, de limites da planície, topográfico e hidrográfico.

- Mapa de feições geomorfológicas fluviais: apresentados na forma de um mapa de modelados atuais, e outro de modelados pretéritos (feições dispesas por toda a planície que indicavam a dinâmica do rio em tempos pretéritos.

Os mapas foram integrados e permitiram a identificação e um entendimento das feições geomorfológicas, definidas por meio dos arranjos de altimetria e semelhanças fisiológicas a outros modelados do grupo (por comparação com as feições da literatura) (Pinheiro \& Pires Neto, 2014). O comportamento da drenagem com todos os seus processos e suas anomalias são pistas dos respectivos ambientes climáticos pretéritos e recentes (Christofoletti, 1980).

\section{Resultados}

A área total de estudo, com ênfase na planície do rio Atibaia, apresenta formato aproximadamente retangular e com eixo principal no sentido nordeste-sudoeste e apresenta área de $34 \mathrm{~km}^{2}$. As elevações da planície variam entre 556 a 560 metros acima do nível do mar, onde se desenvolveram feições indicativas de sua evolução na área.

O rio Atibaia apresenta-se bem estruturado e de sentido na área de estudo, de nordeste-sudoeste. A planície inicia-se após o rio, de sentido sul-norte, que segue a direção das estruturas existentes neste sentido como a zona de cisalhamento de Campinas e Valinhos (IG, 1993; IG, 1995), infletir subitamente para nordeste-sudoeste. As drenagens existentes são córregos que nascem nas vertentes da bacia da planície e deságuam no rio Atibaia.

Esta conformação da planície apresenta acumulação de sedimentos que a podem caracterizar como uma pequena bacia sedimentar.

Em termos de hipsometria, a Figura 4 mostra áreas mais baixas na porção oeste da área de estudo, e o escoamento de águas (jusante) na mesma direção. Esta forma da planície cercada pelas vertentes mais elevadas, cria uma extensa área de captura de águas de chuva, somada as águas dos transbordos do rio Atibaia e descarga de seus afluentes.

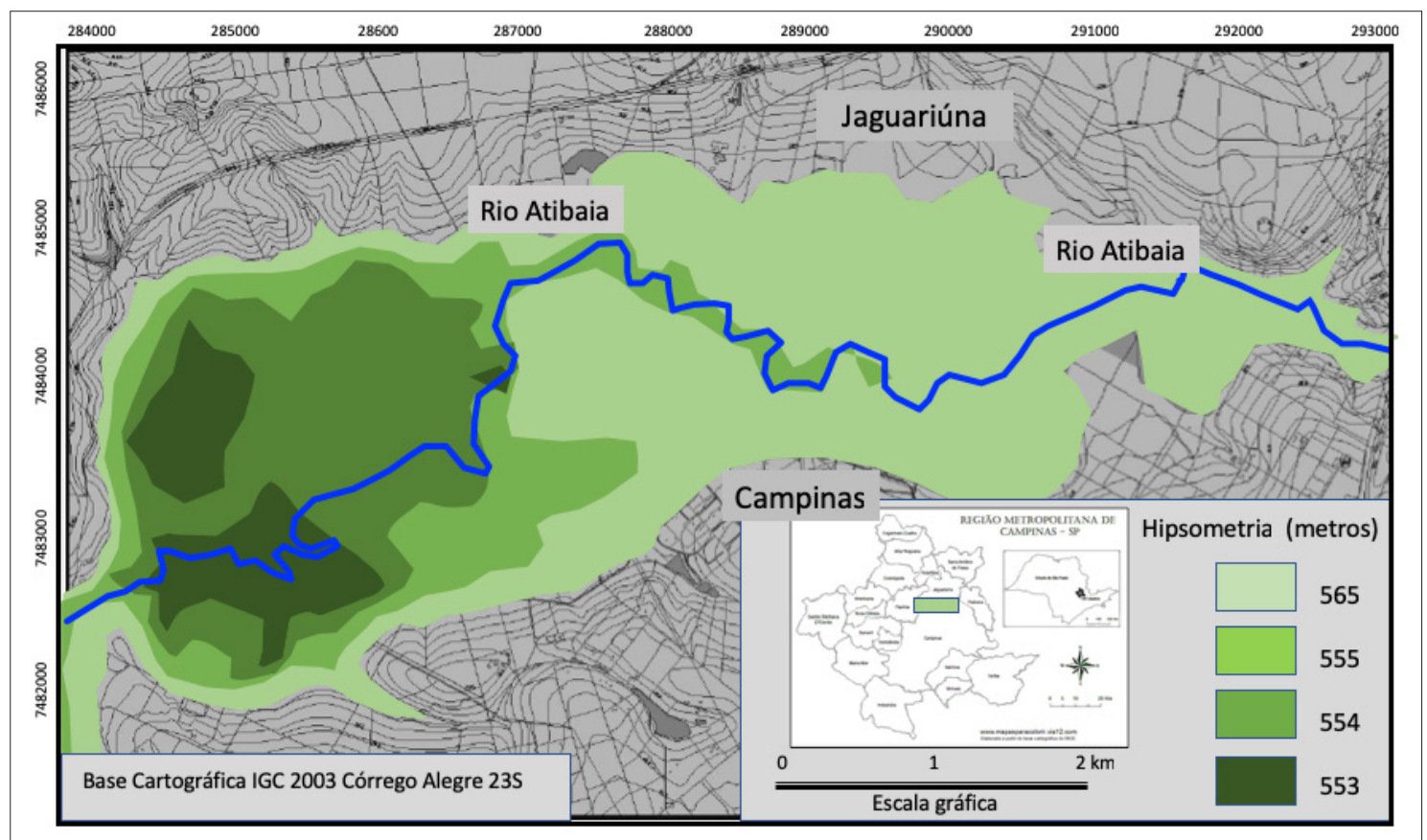

Figura 4. Hipsometria da planície na base cartográfica do IBGE (2003) (Fonte: Guirao, Cisotto \& Barbosa (2012) e Decreto no 17.236 de 14 de janeiro de 2011(2011) 
A planície é estreita no início de sua formação e obedece o encaixamento do rio no respectivo falhamento das rochas graníticas existentes na região. Por volta dos três a quatro quilômetros de seu percurso ocorre uma grande ampliação da área de planície. Isso se deve ao desempedimento da planície de crescer e receber um grande carga de material carreado, provocado talvez pela ocorrência de rochas sedimentares mais erosíveis do Subgrupo Itararé e Coberturas Cenozóicas na porção média da planície e ao afunilamento do canal do rio na porção jusante, devido a presença de rochas de diabásio, menos erosíveis.

A maior elevação na planície na área de estudo é de $625 \mathrm{~m}$ próxima a rodovia SP 340 e a de menor cota, 550 metros, próximo a Rhodia-Solvay. O comprimento do curso do rio Atibaia neste trecho é de 20,67 km. No sentido de montante a jusante, no primeiro quilometro de distância a elevação decresce 40 metros, decorrente da proximidade de um relevo mais acidentado representado pelas rochas gnáissicas e graníticas do Complexo Itapira e da Suite Granítica Jaguariuna, respectivamente. Desse ponto até próximo a Rhodia-Solvay, o rio possui comprimento de 35 metros numa extensão de 19,67 km. As declividades encontradas no primeiro trecho é de 0,004 e no restante, 0,00178 .

Nesta região com baixa declividade do segundo trecho, o rio apresenta-se meandrante com presen- ça de meandros ativos e abandonados, e percorre sobre rochas sedimentares do SubGrupo Itararé, formando extensa planície, com largas margens laterais. A jusante, a planície se afunila e se encaixa devido ao estreitamento das margens decorrentes da presença de diabásio neste trecho do rio.

\subsection{Componentes da planície aluvial}

Os componentes identificados compreendem as feições terraços, dique marginal, bacia de decantação, campos úmidos e meandros (ativos e abandonados) e calha do rio Atibaia. Os paleomeandros, paleocanais e barras de pontal também foram mapeados na planície.

\subsubsection{Terraços}

Eles se localizam em nível mais altos e representam o testemunho evolucional da planície. Quanto mais alto e mais distante do leito atual do rio, mais antigo ele é. Na planície foram definidos 2 terraços, e, portanto, 2 fases de deposição na história de formação da planície.

$\mathrm{Na}$ planície os terraços encontrados possuem diferentes texturas na imagem de satélite; são bem perceptíveis em imagens do Google Earth Pro (Imagem Digital Globe) e nas visitas a campo.

A Figura 3 apresenta os terraços mapeados sendo nomeados de Terraço Nível I, de deposição mais recente, e Terraço Nível II, mais antiga.

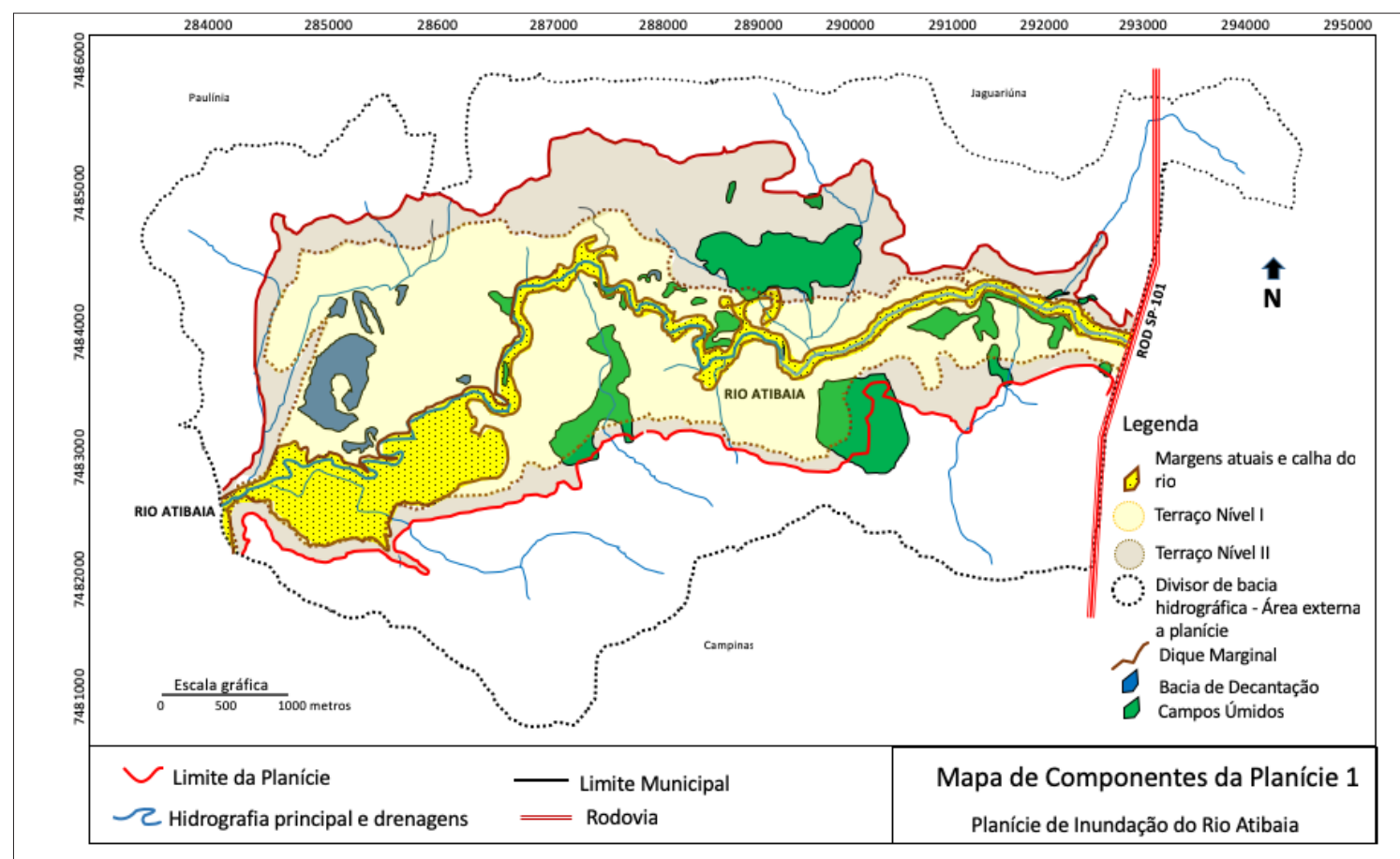

Figura 5. Distribuição dos componentes da planície aluvial do rio Atibaia

\begin{tabular}{c|c|r}
\hline C Terrae Didat. & Campinas, SP & v.15
\end{tabular} 
Os terraços afastam-se de forma gradativa do leito principal a jusante. Os terraços de nível 2, mais longevos da calha do Rio, possui um afastamento desigual entre as margens. No alto curso da planície, na margem esquerda ocorre um afastamento mais abrupto que o da margem direita. Este afastamento obedece, na margem esquerda uma regularidade linear. Já na margem direita, junto a primeira grande retilinização do canal observada, há um grande afastamento que persiste por todo o restante da margem, somente se aproximando no final da Planície. O Terraço de Nível I acompanha na maioria das vezes a forma do Terraço de Nível II.

Desta forma, as bordas de terraço fazem divisa entre as aluviões mais antigas e as atuais. Se destacam por possuírem uma forma abrupta. As bordas determinam a divisão entre os diferentes níveis de terraços encontrados na Planície (Fig. 6).

\subsubsection{Bacias de Decantação}

As bacias de decantação estão localizadas a jusante do curso do rio Atibaia, na margem direita, bem no final da planície. São ao todo sete, sendo que três delas, possuem grandes extensões (Fig. 5).

Nas Figuras 5 e 6, as grandes bacias de decantação ocorrem na porção oeste da área de estudo e na margem direita do rio Atibaia e próximas ao córrego São Francisco.

Essas bacias normalmente possuem uma superfície larga em sua parte central. As bordas apresentam formato curvilíneo, com suas concavidades voltas para o eixo atual do canal do rio. No geral apresentam solos hidromórficos que mantém seu leito úmido com uma grande quantidade de sedimentos depositados. Das sete bacias, seis encontram-se no terreno da Rhodia-Solvay (oeste da área de estudo), onde há uma grande plantação de cana-de-açúcar. Uma sétima bacia, sendo uma das menores que existem encontra-se em uma área com casas na mesma margem, porém no médio curso.

\subsubsection{Diques Marginais}

Os diques marginais ocorrem como limites entre as margens e leito ativo do rio Atibaia e pode retardar uma inundação ou pode reter uma grande quantidade de água muitas vezes por horas ou dias. Os diques distanciam-se da calha do rio na margem esquerda em direção à jusante, que também podem ser testemunhos de diques pretéritos que ainda estão na sua forma original.

A Figura 5 apresenta os diques marginais da planície e as figuras 8 a 9 , as presenças pontuais de sua ocorrência.

Os diques que ocorrem por toda a extensão da calha do rio Atibaia. Na margem direita, os diques ocorrem de forma paralela por toda a margem. $\mathrm{Na}$ margem esquerda ocorre a mesma geomorfologia do montante até o meio da planície. Logo após um grande meandro cuja calha avança por sobre a planície o dique de basalto afasta-se de forma rápida do rio. Esse afastamento cessa de forma longitudinal e formando um ângulo de noventa graus corre em paralelismo com o canal principal. Um pouco antes do término da planície o dique volta abruptamente para próximo do canal.

\subsubsection{Campos Úmidos}

Na porção noroeste da bacia que vai desde a margem direita do Rio Atibaia (para jusante) até a linha férrea para a Rhodia-Solvay uma grande quantidade de nascentes, ou seja, mais de seis por quilômetro quadrado. Na margem esquerda tam-

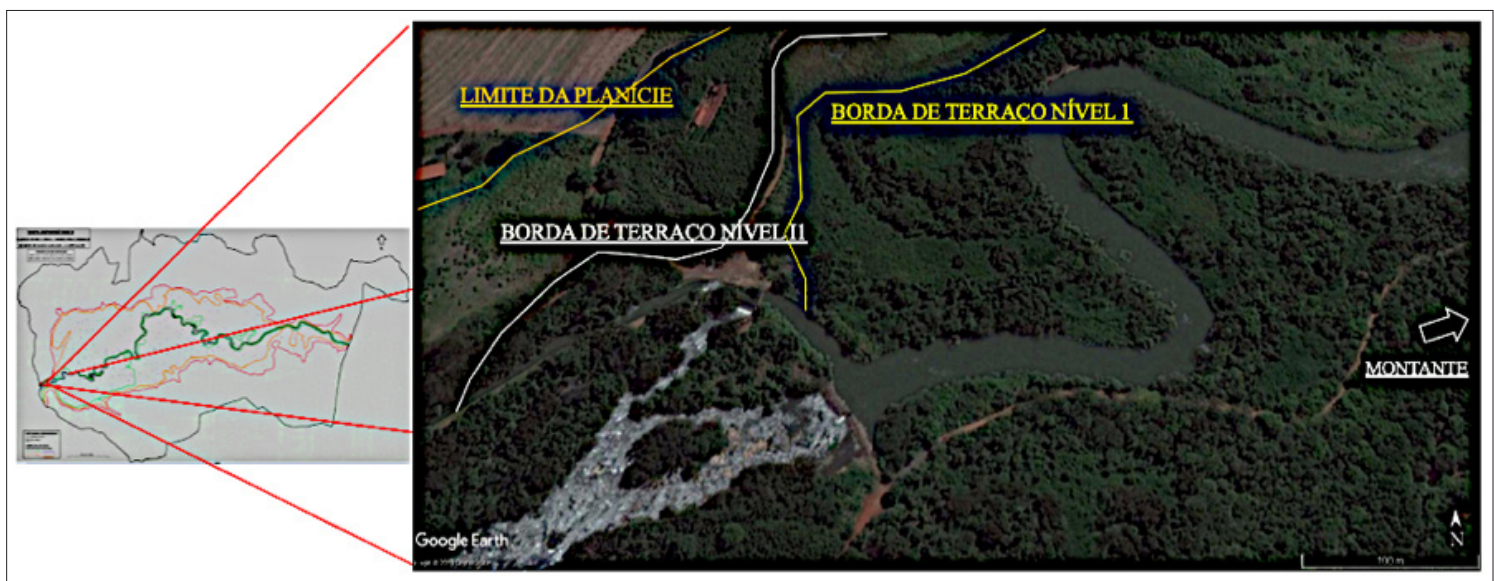

Figura 6. Linha de borda de terraço encontrada na margem esquerda (sentido montante), próxima à planta da RhodiaSolvay - limite oeste da área de estudo (Google Earth, Imagem Digital Globe 2017)

\begin{tabular}{c|c|c|c|c|c}
\hline (C) Terrae Didat. & Campinas, SP & v.15 & $1-18$ & e019029 & 2019 \\
\hline
\end{tabular}




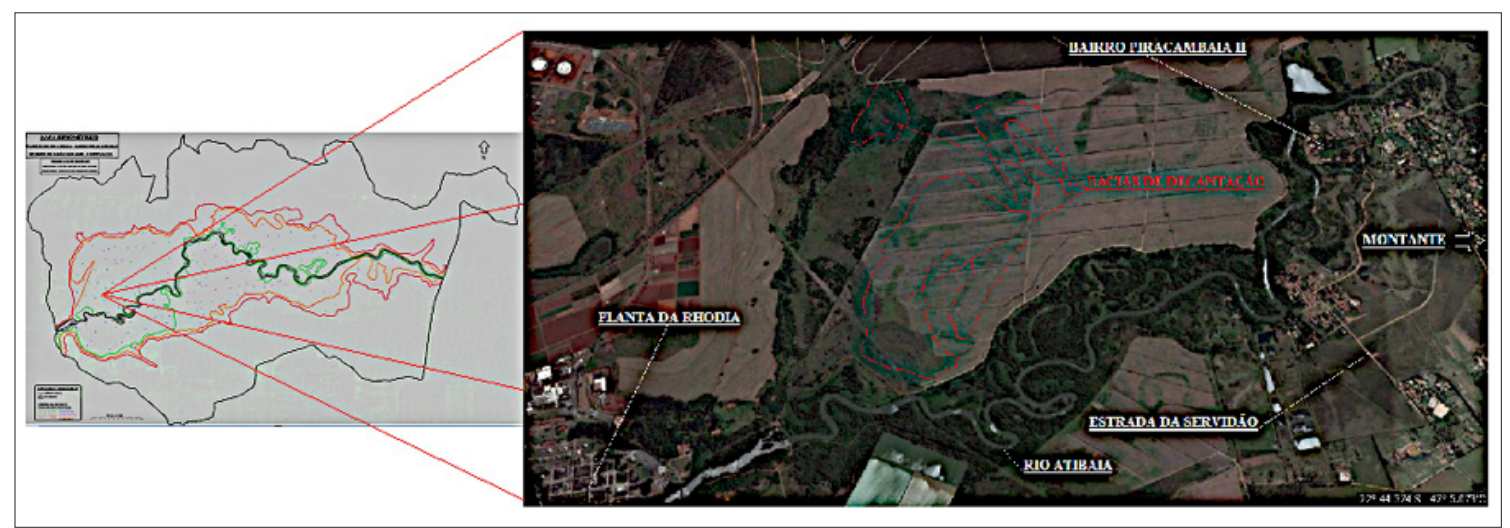

Figura 7. Três grandes bacias de decantação encontradas na planície na margem direita, sentido jusante (Google Earth, Imagem Digital Globe 2016)

bém, foram observadas a mesma quantidade. Ao se traçar uma linha reta entre as duas concentrações de nascentes, verifica-se que na porção central da planície, encontra-se na mesma direção destes campos úmidos. A Figura 5 apresenta os campos úmidos na planície e a Figura 10, o campo úmido e localizações das nascentes.

Os campos úmidos, conhecidos popularmente como várzeas ou brejos, estão localizados a média e alta Planície em ambas as margens.

Além de diferirem das bacias de decantação pelo formato, que são predominantemente retangulares ou hexagonais, possuem na maioria do tempo água em suas extensões. Dos vinte e um campos úmidos encontrados, quatro, são de grandes proporções. Três são de extensões médias e os outros quatorze são menores e muito próximos dos campos maiores, sugerindo assim, que poderiam pertencer em um pretérito não muito distante a fazer parte dos maiores.

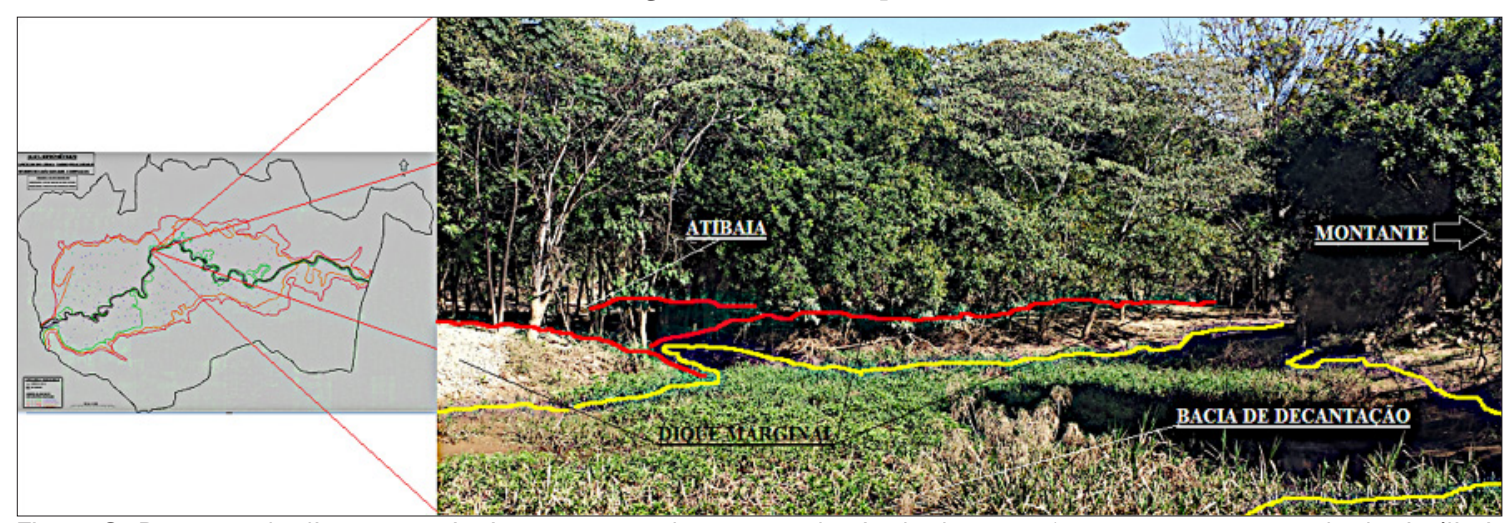

Figura 8. Presença de diques marginais e presença de pequena bacia de decantação na margem esquerda do rio (limitados em vermelho e em amarelo). (Foto: Luís Muraro, 2016)

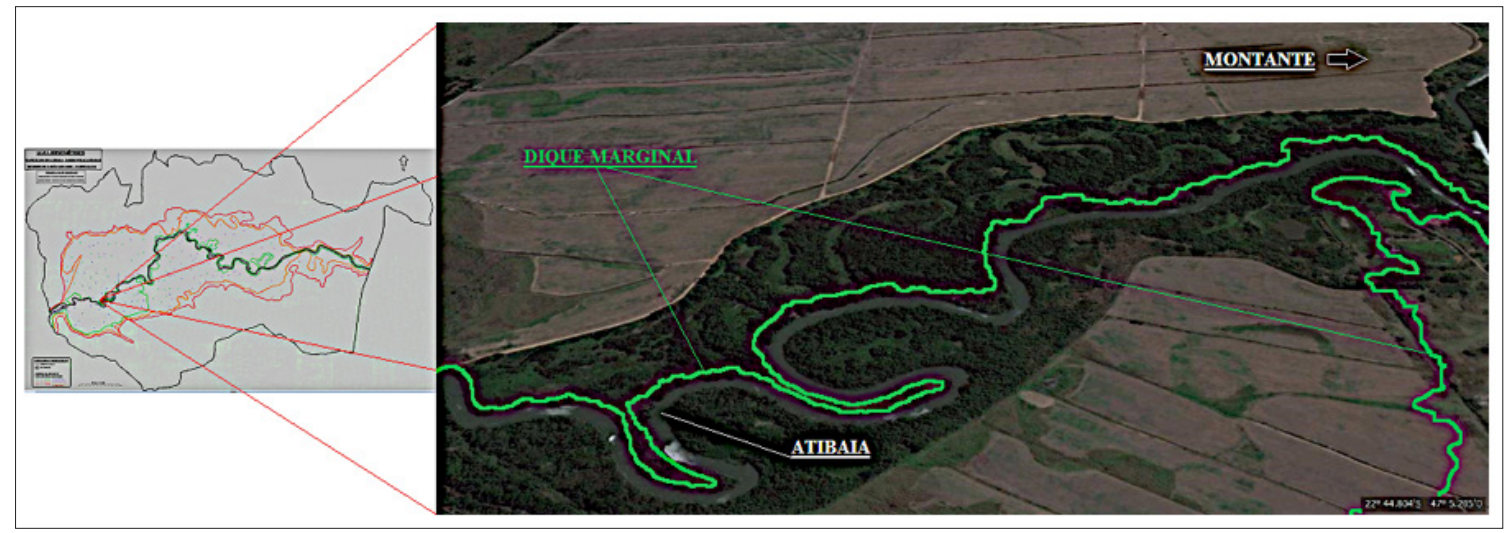

Figura 9. A presença de diques marginais próximos ao rio Atibaia (em verde). No final da planície, na margem direita (sentido jusante) distanciam-se da calha do rio. (Google Earth, Imagem Digital Globe 2016) 


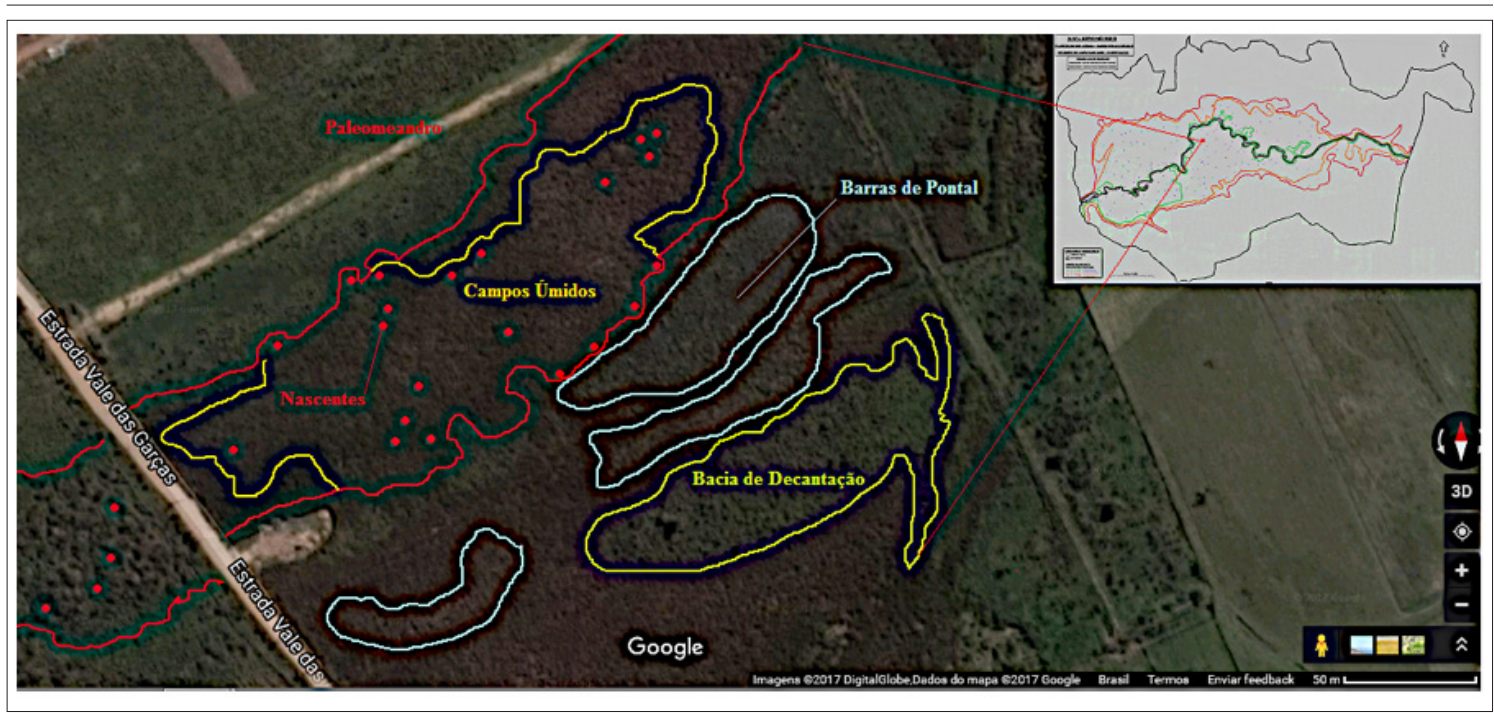

Figura 10. Campo Úmido localizado junto à Estrada das Garças ou Servidão. Ao todo 24 nascentes foram encontradas (Google Earth, Imagem Digital Globe 2016)

\subsubsection{Meandros abandonados e Paleomeandros}

Os meandros abandonados possuem seu fechamento realizado por diques marginais. Os casos encontrados são muitos, uma vez que a planície possui grandes extensões no centro e a jusante.

Os meandros abandonados estão localizados em sua maioria a médio curso, em ambas as margens. O primeiro grupo de meandros encontram-se logo após o rio Atibaia sofrer brusca mudança de curso. Esta mudança ocorre da direção Sul (S) para Sul-Sudoeste (SSO). O rio continua por um certo tempo neste sentido, até que retorna ao seu eixo longitudinal dentro da bacia. Também neste caso o rio sofre outra brusca mudança de curso, só que desta vez na direção Noroeste (NO) para Sudeste (SE). Os meandros localizam-se antes desta brusca mudança na margem esquerda.

A Figura 11 apresenta a planície e a disposição dos meandros e paleodrenagens.

As paleodrenagens presentes na planície estão representadas por depósitos fluviais e representam uma drenagem pretérita. Podem ser encontradas paleodrenagens, como paleocanais (Christofoletti, 1980), paleomeandros e meandros abandonados (Zancopé, 2009) com seus preenchimentos sedimentares (Suguio, 2003).

Os paleocanais são encontrados em ambas as margens, sendo ao todo quatorze. No começo da planície oito deles estão localizados no início e médio curso, sendo dois na margem direita e seis na margem esquerda. Nota-se que todos acompanham o lineamento do canal principal. Os demais localizam-se ao longo da calha do Rio.

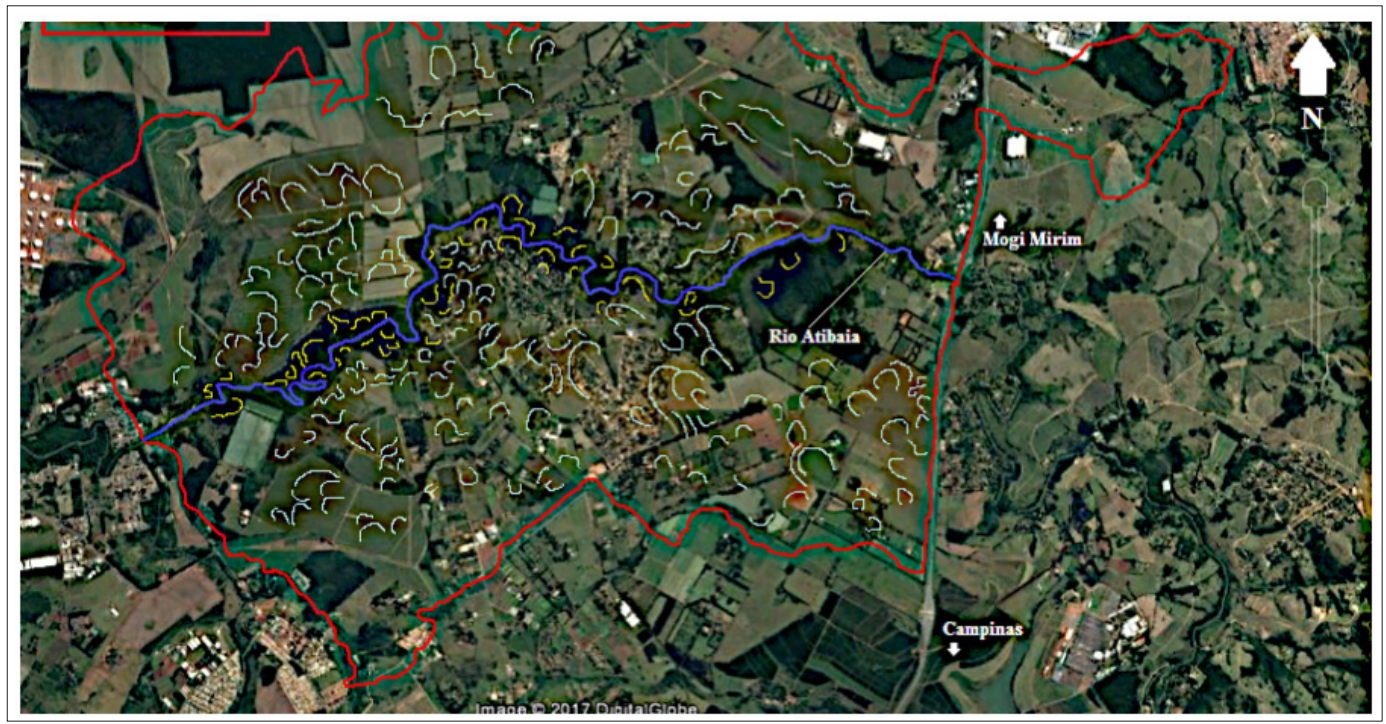

Figura 11. Distribuição dos meandros abandonados, paleocanais e paleomeandros na planície do rio Atibaia (C) Terrae Didat. Campinas, $\mathrm{SP}$ v. 15 \begin{tabular}{l|l}
$1-18$ & $\mathrm{e} 019029$
\end{tabular} 2019 


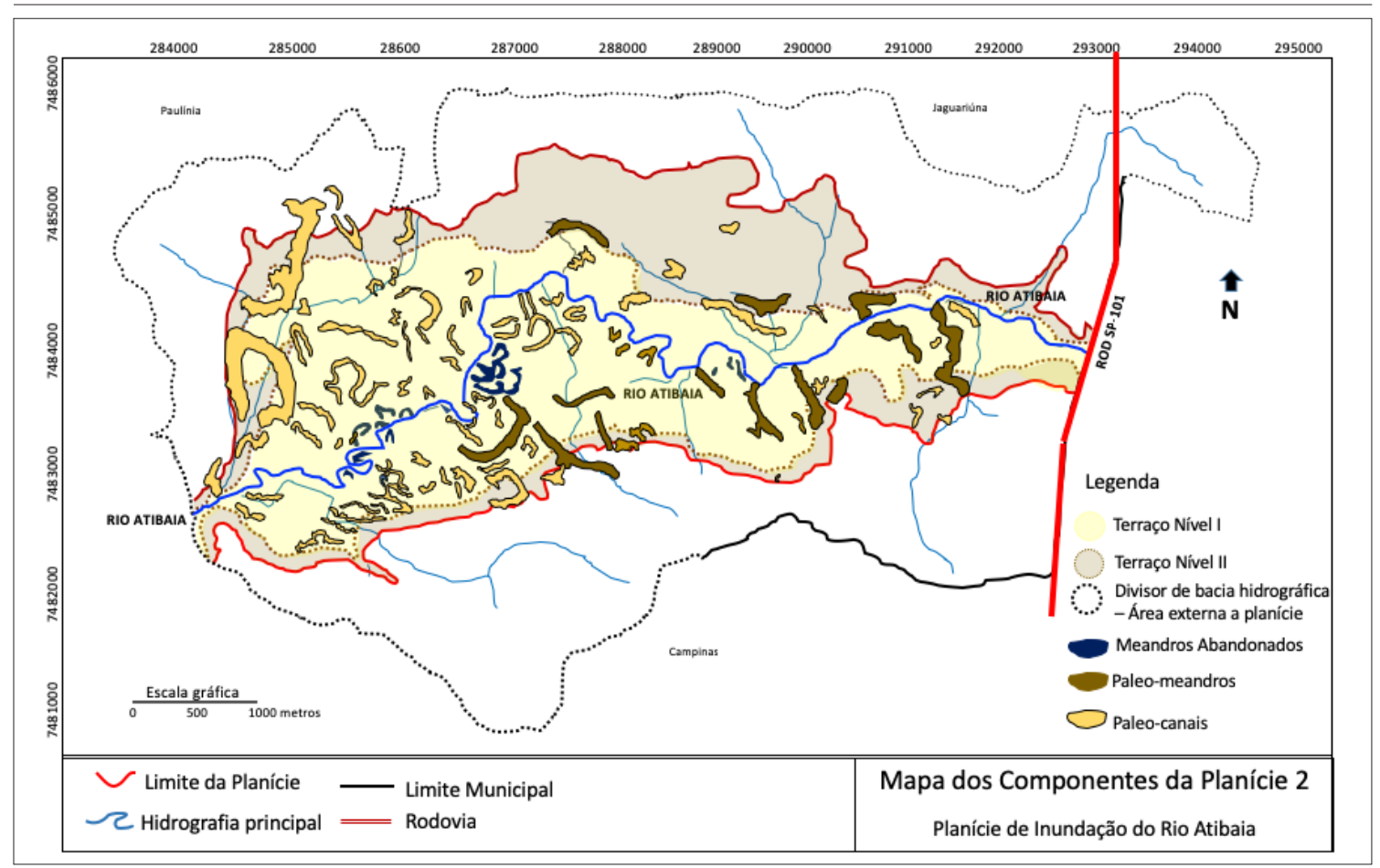

Figura 12. Distribuição dos meandros abandonados, paleocanais e paleomeandros na planície do rio Atibaia

A quantidade de paleomeandros é grande, sendo catalogados setenta e nove. $\mathrm{Na}$ margem esquerda, existem cinquenta e cinco, sendo que, dos vinte e oito encontrados na parte final, dezenove estão localizados na parte mais larga da planície. Os demais encontram-se no terraço de nível II. Dez estão muito próximos da calha Rio a médio curso. Os demais espalham-se de forma aleatória na parte alta da planície. Na margem direita, quinze se localizam próxima ao canal do Rio. Os outros oito, são maiores que os demais e estão localizados ao longo da margem direita.

\subsubsection{Barras de Pontal}

As barras de pontal são muito comuns em sistemas fluviais meandrantes, como é o caso do Atibaia nesta região. Mostram o deslocamento do canal principal pela Planície. Elas são morfologicamente constituídas de linha convexas sucessivas (Riccomini \& Coimbra, 1993). São conhecidas também como Point Bars (Figura 13).

No caso as barras de pontal são pretéritas e encontradas distantes da calha do rio, porém próximos as paleodrenagens no Terraço de nível I.

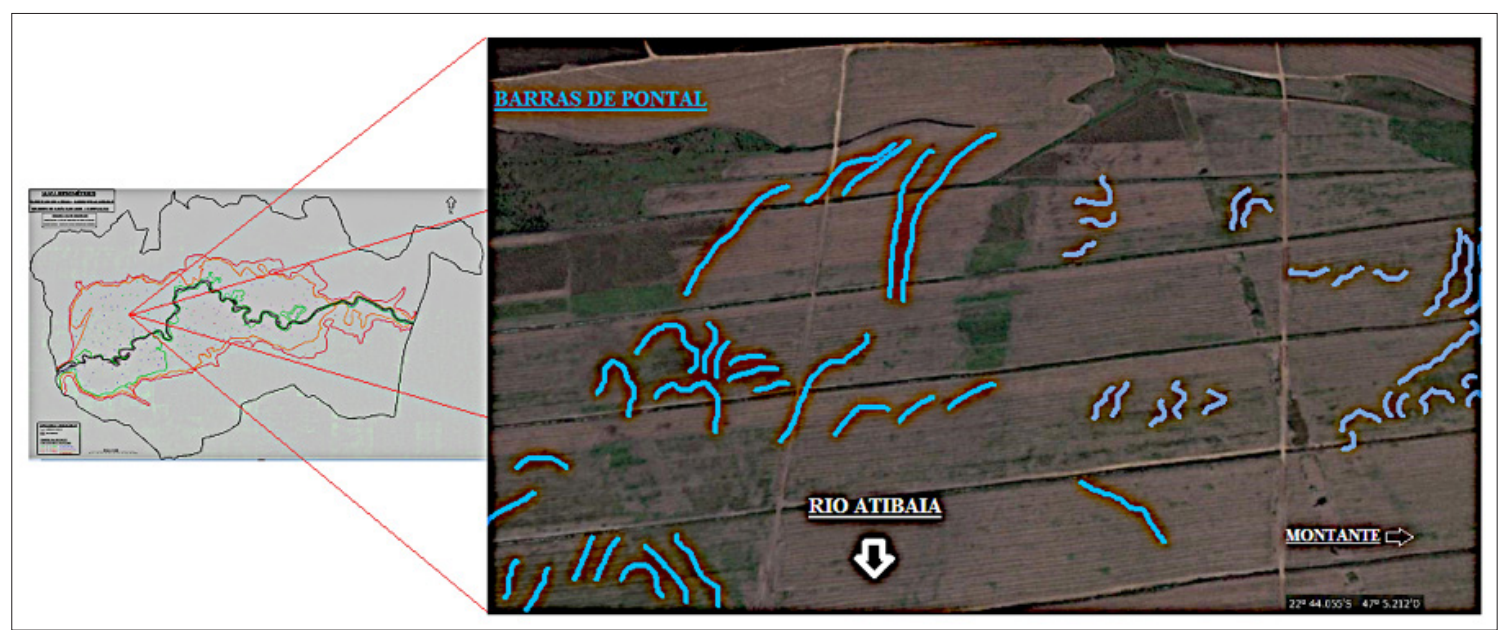

Figura 13. As Barras de Pontal (em azul) ficam bem evidenciadas na foto (Google Earth, Imagem Digital Globe 2017) 


\subsubsection{Demais componentes da planície}

Nascentes na Planície - as nascentes são afloramentos de água que se formam nos pontos de descarga superficial dos aquíferos. Geralmente estão localizados nos pontos mais baixos dos aquíferos livres (Pereira et al. 2011). É uma área onde ocorre a exsudação natural das águas subterrâneas, a qual possibilita a formação de lagoas, lagos, canais de rios e demais exemplos hidrográficos. Muitas nascentes estão localizadas em áreas de terrenos argilosos, sendo algumas poucas perenes. Contudo em períodos chuvosos ocorre a subida do nível potenciométrico ocasionando o surgimento de várias nascentes.

Ao total existem 116 nascentes na área da Planície incluindo as que se encontram no divisor. A maioria delas são intermitentes 89 e outras 27 são perenes. A Figura 14 apresenta uma nascente dentro da planície.

Pequenas elevações - são feições de pequenos morros convexos que existem sobre a superfície da mesma (Figura 15 e 16). Estas elevações são recorrentes na planície e são resultantes de processos de dissecação que ocorreram na área. Estas feições apresentam uma diferença de elevação de 1 a 2 metros.

Anomalias de Drenagem - são de fácil percepção pois o rio possui o canal retilíneo quando estão sobre elas. Outra forma de percebê-las são as mudanças bruscas de direção do curso do rio (Almeida, 1964). Essa anomalia é facilmente perceptível na planície, pois o padrão se altera de forma bem acentuada e são encontradas ainda no início da mesma, quando ainda está sobre as estruturas do cristalino.

\subsection{A Planície do rio Atibaia}

A planície do rio Atibaia, da área de estudo, situa-se entre a Depressão Periférica e o Planalto de
Jundiaí, onde predominam as unidades de relevo Colinas Amplas (IG, 1993), e estão sobrepostos em rochas sedimentares do Grupo Tubarão - SubGrupo Itararé e corpos de sills e diques de diabásios.

De acordo com a classificação de Ab'Saber (1970), a planície ocorre no $4^{\circ}$ táxon, onde as formas e feições podem ser melhor observadas. As morfoesculturas menores apresentadas, na ordem de metros são classificadas e analisadas a partir do no $5^{\circ}$ táxon. No caso da planície os táxons já podem ser observados na escala 1:10.000. Isso se deve ao fato de que muitas das morfoesculturas apesar de serem classificadas no mesmo táxon, possuem tamanhos diferenciados.

A morfoescultura é a principal fonte dos estudos sobre a Planície, já que representa a compartimentação e a zonalidade do mesmo (Ross, 2005). A morfoescultura, permitiu observar processos erosivos, transportadores e deposicionais sedimentares no interior da Planície. Não deve ser esquecida a ação antrópica, uma vez que interfere fortemente na morfoescultura. O desmatamento, a pavimentação, a drenagem, as terraplanagens e em pretérito recente a retirada de areia, modificam fortemente as dinâmicas morfoesculturais e induzem a geração novas formas de relevo. Há ainda a erosão provocada pela ação do homem ou pelo próprio comportamento do Rio Atibaia.

Na planície é encontrado a montante o embasamento cristalino, de relevo acidentado, representado pelas suítes graníticas e rochas gnáissicas do Complexo Itapira. No centro e a jusante há a presença de diabásios e início da Depressão Periférica da Bacia do Paraná.

A montante, ela está sobre regiões de rochas e complexos cristalinos, e terrenos de maiores declividades, portanto com predomínio dos processos

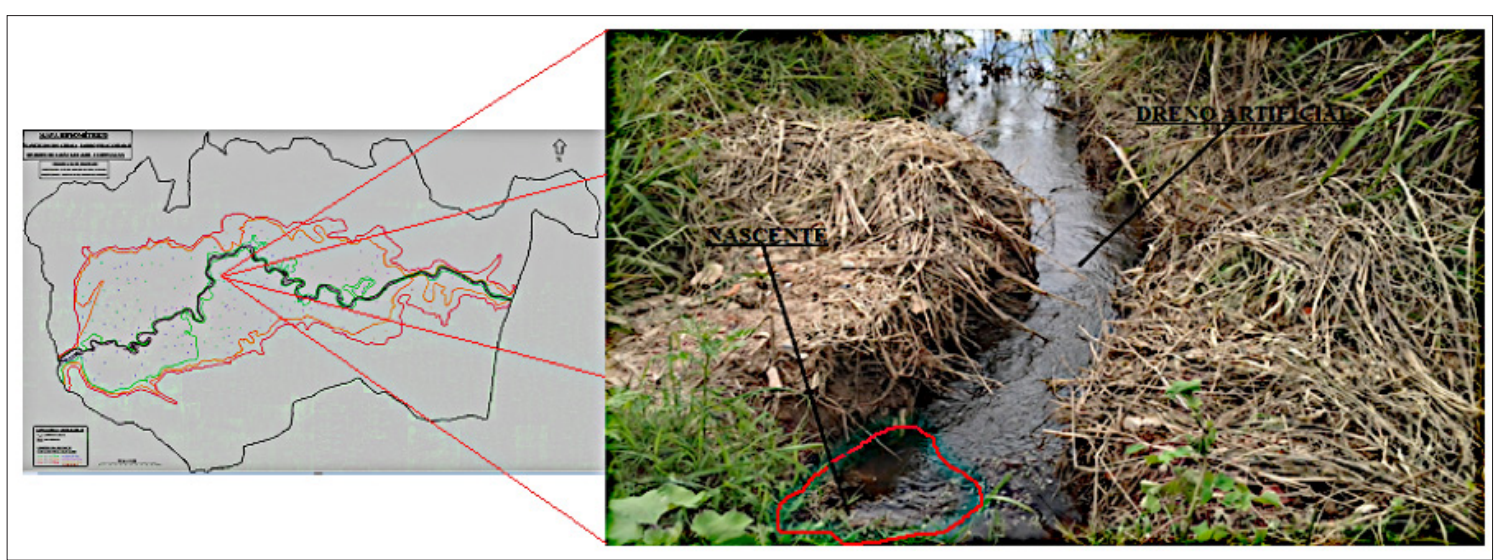

Figura 14. Nascente encontrada junto à rua Tucano Toco, no Bairro Piracambaia I, porção central da planície próxima a calha do rio Atibaia (Foto: Luís Muraro 17/01/16)

\begin{tabular}{c|c}
\hline C Terrae Didat. & Campinas, SP \\
\hline \multicolumn{1}{|c}{14}
\end{tabular}




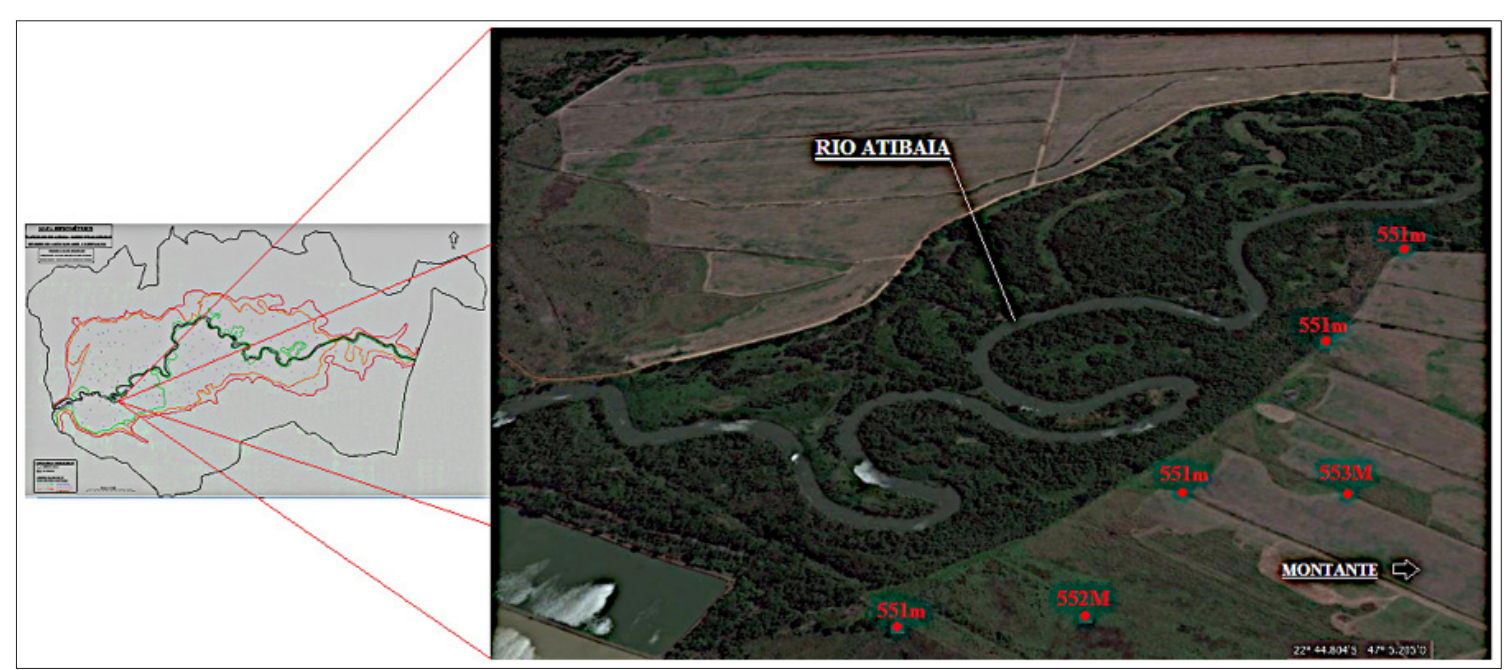

Figura 15. Alguns topos de morros encontrados dentro da planície. (Google Earth, Imagem Digital Globe 2016)

mais erosivos. No centro e a jusante sofre processo de sedimentação, decorrente da presença de rochas sedimentares, mais friáveis, e situadas em terrenos mais colinosos. O rio é considerado meandrante, uma vez que a baixa declividade encontrada na região pode reger uma dinâmica mais favorável a formação destes componentes.

Há presenças de dois terraços na área de estudo, resultado de uma evolução lateral da planície (Storani \& Perez, 2015). No Terraço de Nível I, mais recente, as feições pretéritas prevalecem, como paleocanais e paleomeandros por toda sua extensão.

A planície é ladeada por diques marginais que agem como barreiras naturais provocando dois tipos de ações sobre o escoamento das água (Menezes, 2018). O primeiro deles é quando impede o transbordo do canal. Neste ocorre o aumento da velocidade de escoamento no leito menor. O segundo, quando já ocorreu o extravazamento das águas, ele age de forma inversa, ou seja, represando-as. Há ainda a presença de barras laterais mais afastadas do canal principal e possuem altura menor que os diques. Todo o regime de escoamento superficial do alto e médio cursos da planície, sofrem influência destas feições geomorfológicas.

Os meandros abandonados situados próximos às margens do rio Atibaia mostram fases recentes de diversas migrações da calha do rio na porção média da área de estudo, tanto no sentido noroeste como no sentido sudeste. Estas migrações parecem relacionar-se com as grandes estruturas geológicas que regem toda a extensão do rio Atibaia, e a neo-

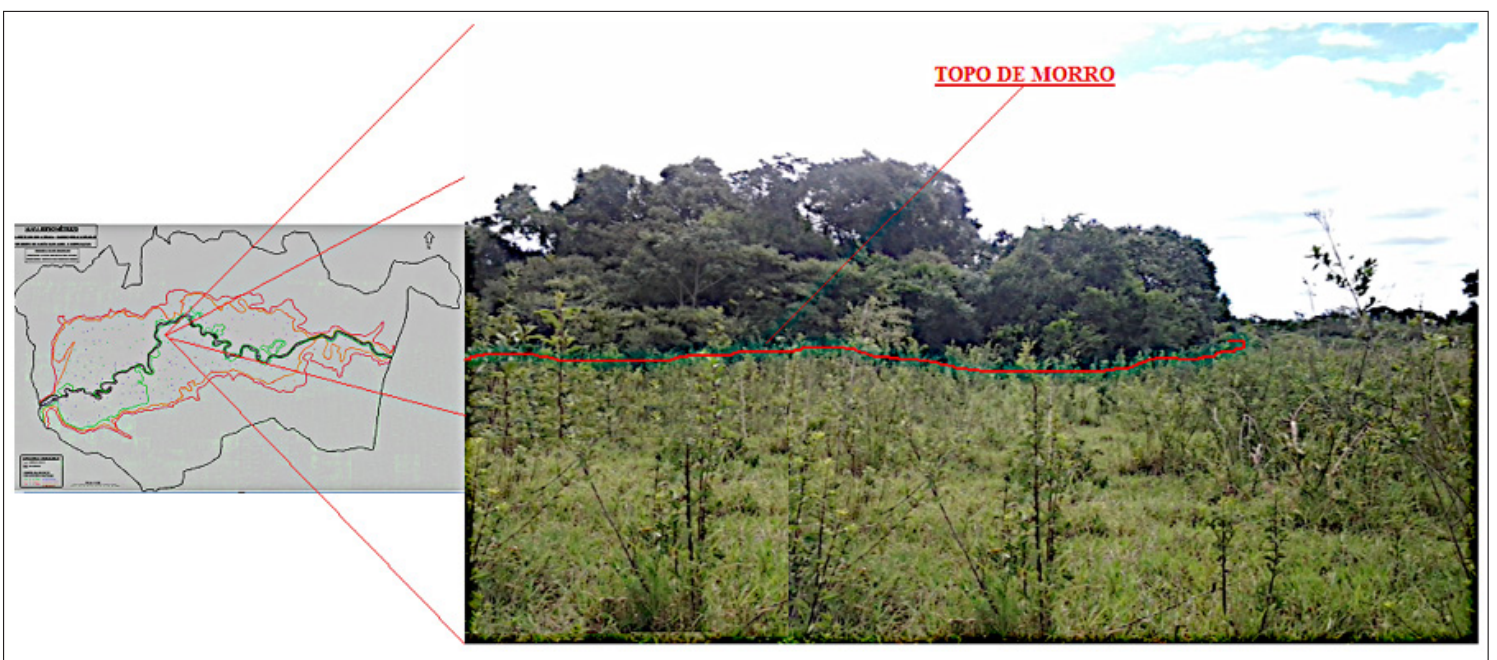

Figura 16. Topo de morro (em vermelho) com altitude aproximada de 553m concentra uma mata de transição entre os biomas Cerrado e Mata Atlântica. Foto tirada na estrada da Servidão, sentido Bairro Piracambaia II (Foto: Luís Muraro, 2016) 
tectônica. Na área de estudo, Pires Neto (1996) define a presença do Bloco Estrutural Americana, limitado por grandes lineamentos estruturais, que cortam as rochas sedimentares existentes. Este Bloco, que reflete a atividade das estruturas em várias épocas do Quaternário, apresenta leve adernamento a noroeste da área, coerente com a declividade existente na planície.

Dentro da planície foram identificadas barras de pontal afastadas das margens do rio que também mostra a evolução do rio na planície. Os campos úmidos apresentam típica vegetação e indicam afloramento do nível freático como também ocorrência de nascentes. As bacias de decantação encontradas a porção oeste da área de estudo encontram-se nos locais mais baixos da planície.

\section{Conclusão}

A larga planície aluvial do rio Atibaia é resultante de situações favoráveis que permitiram sua evolução lateral. A presença de afunilamentos, decorrentes da presença de rochas gnáissicas e graníticas a montante, e diabásios a jusante, como a ocorrência de um relevo menos acidentado (rochas sedimentares do Subgrupo Itararé e coberturas cenozoicas) na porção média, e o neotectonismo, propiciaram a formação da planície e de sua evolução. A baixa declividade longitudinal da planície e sua extensão lateral aplainada, e a situação meandrante do rio na área são as características encontradas nesta região de transição entre o Planalto Atlântico e a Depressão Periférica.

No estudo sobre os terraços identificaram-se duas fases importantes de deposição dos sedimentos. A mais antiga (Terraço de Nível II), de maior desenvolvimento na margem direita do rio, pode indicar o maior desenvolvimento da planície nesta fase. O Terraço de Nível I já mostra a configuração recente, com a migração lateral de vários sentidos. Na fase mais atual mostra migrações laterais de meandros abandonados de sentido noroeste e sudeste na porção média do rio Atibaia. Os diques marginais delimitam a dinâmica atual do rio Atibaia, onde processos de assoreamento e erosão das margens atuam. Os campos úmidos apresentam a ocorrência de nascentes e afloramento do aquífero freático e as bacias de decantação a porção mais baixas da planície onde as águas do rio, de escoamento superficial e das chuvas se dirigem.

A planície está fortemente relacionada também com a variação da vazão do rio e de seus extremos (cheias e secas); o maior entendimento das planícies podem contribuir com outras áreas do conhecimento no sentido de proteger este ecossistema e gerenciar seus riscos a ocupação humana.

\section{Referências}

Ab'Saber, A. N. (1970). Domínios morfoclimáticos e províncias fitogeográficas no Brasil. Orientação, São Paulo, n. 3, p. 45-48, 1967. [Republicado em Grandes paisagens brasileiras. São Paulo: Eca, 1970a; e como parte do artigo "Províncias geológicas e domínios morfoclimáticos no Brasil”. São Paulo, Geomorfologia, (20), 1-26.

Alexander, J.; \& Marriot, S. B. (1999). Introduction. In: Marriot, S.; Alexander, J. (Eds.). Floodplains. Interdisciplinary Approaches. Special Publication, 163. Geological Society of London, London, pp. 1-13 (Special Publication).

Almeida, F. F. M. de. (1964). Fundamentos geológicos do relevo paulista. Boletim do Instituto Geográfico e Geológico, vol. 1, 167-273.

Almeida, F. F. M. de. (2018). Fundamentos geológicos do relevo paulista. Revista do Instituto Geológico, 39(3), 9-75. doi: https://doi.org/10.33958/revig. v39i3.600.

Bayer, M.; \& Zancopé, M.H.de C. (2014). Ambientes sedimentares da planície aluvial do rio Araguaia. Revista Brasileira de Geomorfologia, 15(2), 203-220. doi: http://dx.doi.org/10.20502/rbg.v15i2.414.

Benson, C. \& Clay E. J. (2003). Disasters, Vulnerability and the Global Economy. In: Kreimer, A.; Arnold, M. (eds.). (2003). The Future Disaster Risk: Building Safer Cities. Disaster Risk Management Series n. 3, Washington, D.C. p. 3-32.

Brunke, M. \& Gonser, T. (1997). The ecological significance of Exchange processes between rivers and groundwater. Freshwater Biology, 37, 1-33.

Carneiro, C. D. R. (2018). Os "Fundamentos geológicos do relevo paulista" nos dias atuais. São Paulo: Revista do Instituto Geológico, 39(3), 1-8. doi: https:// doi.org/10.33958/revig.v39i3.599.

Charlton, R. (2008). Fundamentals of fluvial geomorphology. London, UK: Ed. Routledge.

Christofoletti, A. (1980). Geomorfologia. (2 ed.). São Paulo, SP, Brasil: Ed. Blücher, 188p.

Prefeitura Municipal de Campinas (2011). Decreto no. 17.236 de 14 de janeiro de 2011. Dispõe sobre as medidas preventivas e interdição de imóveis localizados em áreas sujeitas a inundação, no município de Campinas, e dá outras providências. Diário Oficial, 15 de janeiro de 2011, no 10.058-Ano XLI, páginas 1 e 2.

Empresa Brasileira de Pesquisa Agropecuária [Embrapa Solos] (2018). Sistema Brasileiro de Classificação de Solos. ( $3^{a}$ ed. Revista e ampliada). Brasília: Ministério da Agricultura, Pecuária e Abastecimento. 
Guirao, A.; Cisotto, M. F.; Barbosa, R. V. (2012). Vulnerabilidade por inundação na área de várzea do rio Atibaia no município de Campinas. Revista Geonorte. Ed. Esp., 3(4), 1380-1390. URL: www. periodicos.ufam.edu.br/revista-geonorte/article/ view/2030/1904.

Hatton, T. \& Evans, R. (1998). Dependence of ecosystems on groundwater and its significance to Australia. Occasional Paper 12/98. Land and Water Resources Research and Development Corporation. Camberra. URL: htpps://library.dbca.wa.gov.au/static/ FullTextFiles/018743.pdf.

Instituto Brasileiro de Geografia e Estatística [IBGE] (1991). Manual técnico de geomorfologia. 181p. $\left(2^{\mathrm{a}}\right.$ ed.). Rio de Janeiro, RJ: IBGE.

Instituto Geológico [IG] (1993). Subsídios do meio físico-geológico ao planejamento do município de Campinas $(\mathrm{SP})$, Instituto Geológico. Programa Cartas Geológicas e Geotécnicas para o planejamento ambiental na região entre Sorocaba e Campinas. São Paulo, Instituto Geológico. 3v.

Instituto Geológico [IG] (1995). Subsídios para o planejamento regional e urbano do meio físico na porção média da Bacia do Rio Piracicaba, SP. Programa Cartas Geológicas e Geotécnicas para o planejamento ambiental na região entre Sorocaba e Campinas. São Paulo, Instituto Geológico. 4v.

Instituto Geológico [IG] (2009). Mapa geológico do município de Campinas. Instituto Geológico, Volume II, Relatórios Técnicos. p. 127.

Leinz, V. \& Amaral, S. E. do. (1995). Geologia do Brasil. São Paulo: Cia. Ed. Nacional.

Marriot, S. B. (2004). Floodplain. In: Goudie, A. S. (Ed.). (2004). Encyclopedia of Geomorphology (Vol.1, 381-384), London, UK: Routledge.

Menezes, D.J. (2018). Proposta metodológica para análise espaço-temporal de inundações: aplicação na área urbana de Alegrete, RS, Tese de Doutorado, Universidade Federal de Santa Maria. Santa Maria, RS, Brasil.

Muraro, L. E. O., Pereira, S. Y., Pereira, P. R. B. (2016). O potencial de reservação de água subterrânea na planície de inundação do rio Atibaia, distrito de Barão Geraldo, Campinas, SP. Anais XIX Congresso Brasileiro de Águas Subterrâneas, Campinas, SP, Brasil. URL: https://aguassubterraneas.abas.org/asubterraneas/article/view/28795

Murray, B. R.; Zeppel, M. J. B.; Grant, C. H.; \& Eamus, D. (2003). Groundwater-dependent ecosystems in Australia: it's more than just water for rivers. Ecological Management and Restoration, vol. 4, issue 2, p. 110-113. doi: https://doi.org/10.1046/j14428903.2003.00144.x

Pellogia, A. U. G. (2005). A cidade, as vertentes e as várzeas: a transformação do relevo pela ação do homem no município de São Paulo. Revista do Departamento de Geografia, 16 (2005) 24-31. URL: www.revistas.usp.br/rdg/article/view/47281/51017
Pereira, P. H. V.; Pereira, S. Y.; Yoshinaga, A.; \& Pereira, P. R. B. (2011). Nascentes: Análise e discussão dos conceitos existentes. Fórum Ambiental da Alta Paulista, v.7, n.2, 2011. URL: https://www.amigosdanatureza.org.br/publicacoes/index.php/forum_ ambiental/.../109

Pereira, S. Y. (1997). Proposta de representação cartográfica na avaliação hidrogeológica para o estudo de planejamento e meio ambiente, exemplo da Região Metropolitana de Campinas, SP. Tese de Doutorado, USP, São Paulo, Brasil.

Perez Fo., A.; Donzelli, J. L.; \& Lepsch, I. F. (1980). Relação solos geomorfologia em várzea do rio Mogi Guaçu (SP). Revista Brasileira de Ciência do Solo, 4(3), 181-187.

Pinheiro, M. R. \& Pires Neto, A. G. (2014). Reflexões sobre a gênese da Serra Geral e da Depressão Periférica Paulista: o exemplo da região da Serra de São Pedro e do baixo Piracicaba, SP. Revista do Instituto Geológico. V.15, no.1, SP. URL: ppegeo.igc.usp. br/index.php/rig/article/view/8957

Pires Neto, A. G. (1996). Estudo morfotectônico das bacias hidrográficas dos rios Piracicaba, Capivari, Jundiaí e áreas adjacentes no Planalto Atlântico e Depressão Periférica. Rio Claro, SP. Proj. CNPq 150011/94-6, IGCE UNESP.

Popp, J. H. (1998). Geologia Geral. (5 ${ }^{\mathrm{a}}$ ed.). Rio de Janeiro, RJ: Record.

Riccomini, C. \& Coimbra, A. M. (1993). Sedimentação em rios entrelaçados e anastomosados,. Boletim IG-USP, Instituto de Geociências. URL: http://www .revistas.usp.br/bigsd/article/viewFile/45350/48962

Rinaldi, M.; Gurnell, A. M.; González del Tánago, M.; Bussettini, M.; \& Hendriks, D. (2016) Classification of river morphology and hydrology to support management and restoration. Aquat Sci 78:17-33.

Rocha, P. C. (2011). Sistemas rio-planície de inundação: Geomorfologia e conectividade hidrodinâmica. Caderno Prudentino de Geografia, n.33, v.1, p50-67, jan./jul. 2011. URL: revista.fct.unesp.br/index. php/cpg/article/view/1953.

Rodhe, M. M.; Ray, F.; \& Howard, J. (2017). A global synthesis of managing groundwater dependent ecosystems under sustainable groundwater policy. Groundwater, 55(3), 293-301

Rosgen, D. L. (1994). A classification of natural rivers. Catena 22, 169-199.

Ross, J. (2005). Geografia do Brasil. 5 a ed. São Paulo: Universidade de São Paulo.

Serviço Geológico do Brasil [CPRM] (2013). Ação emergencial para reconhecimento de áreas e alto e muito alto risco a movimentos de massas e enchentes. Campinas, SP, maio de 2013, SP_CPS_SR_01_CPRM, Vale das Garças - Vila Holândia (CA-48-CA47). 1 p. URL: http://rigeo.cprm.gov.br/jspui/handle/ doc/20261 
Serviço Geológico do Brasil [CPRM] (1974). Manual de geologia. URL: http://rigeo.cprm.gov.br/jspui/ handle/doc/4802.

Stanford, J. A. \& Ward, J. V. (1993). Ecological connectivity in alluvial river ecosystems and its disruption by flow regulation. Regulated rivers: research \& management, p.105-119, v. 2.

Storani, D. L.; \& Perez Fo., A. (2015). Novas informações sobre geocronologia em níveis de baixo terraços fluviais do rio Mogi Guaçu, SP, Brasil.Revista Brasileira de Geomorfologia, 16(2), 191-199. doi: http://dx.doi.org/10.20502/rbg.v16i2.656.

Strick, R. J. P.; Ashworth, P. J.; Awcock, G.; \& Lewin, J. (2018). Morphology and spacing of river meander scrolls. Geomorphology, 310, 57-68.

Suguio, K. (2003). Geologia sedimentar. São Paulo, SP: Blücher.

Tannus, J. L. S. \& Assis, M. A. (2003). Composição de espécies vasculares de campo sujo e campo úmido em área de cerrado, Itirapina - SP, Brasil. Revista Brasil, 27, 489-506.

The World Bank. (2006). Groundwater Dependent Ecosystems, the challenge of balanced and adequate conservation. Briefing Note Series. Sustainable Groundwater Management. Concepts and Tools.
GW-Mate. Note 15. URL: http://documents. worldbank.org/curated/en/407851468138596688/ pdf/442960BRI0BOX31Jan0110200601 public1. pdf.

Tucci, C. E. M. (2012). Gestão de inundações urbanas. Brasilia, DF: Ministério das Cidades, Governo Federal.

Vendrame, I. F. \& Lopes W. A. B. (2015). Análise do crescimento urbano e seus efeitos na mudança da dinâmica de escoamento superficial da bacia do Pararangaba. Anais XII Simpósio Brasileiro de Sensoriamento Remoto. Goiânia, GO. URL: marte. sid.inpe.br/col/ltid.inpe.br/sbsr/2004/11.18.20.11/ doc/2555.pdf.

Verstappen, H. T. (1983). Applied Geomorphology (Geomorphological Surveys for Environmental Development). New York, USA: Elsevier.

Zancopé, M. H. C. (2008). Análise morfodinâmica do rio Mogi Guaçu. Tese de Doutorado, Campinas, SP, Brasil, Unicamp.

Zancopé, M. H. C. \& Perez Fo., A. (2006). Consideração a respeito a distribuição das planícies aluviais do rio Mogi Guaçu. Revista Brasileira de Geomorfologia, 7(1), 65-71. doi: http://dx.doi.org/10.20502/ rbg.v7i1.161. 